\title{
Understanding Agrarian Crisis: A Participatory and Qualitative Systemic Analysis
}

\author{
Vijay Hanmant Honkalaskar (Corresponding author) \\ Sulokchetana Pratishthan, Himalay Bungalow, Adarsha Colony, \\ Tamjai Nagar, Satara, 415002 \\ State: Maharashtra, India
}

Tel: 91-8600106188, E-mail: honkalaskar@gmail.com

Nikhilesh D. Bagde

Research Scholar, CTARA, Indian Institute of Technology Bombay,

Mumbai, 400076, State: Maharashtra, India

Tel: 91-9404249260, E-mail address: sumantalone@gmail.com

Shireesh B. Kedare

Professor, Department of Energy Science and Engineering,

Indian Institute of Technology Bombay, Powai, Mumbai 400076

State: Maharashtra, India

Tel: 91- 222576 7835, E-mail: sbkedare@iitb.ac.in

Received: January 9, 2018

doi:10.5296/jas.v6i1.12770
Accepted: January 26, 2018

URL: https://doi.org/10.5296/jas.v6i1.12770

\begin{abstract}
As yet, most of the attempts undertaken to study the agrarian crisis in India have lacked systemic analysis of such a complex, non-linear, and dynamic problem that spans a number of facets including social, cultural, agricultural, ecological, economical, and political dimensions. The present study attempts to carry out a participatory investigation of the crisis with a number of farmers from six different villages to understand the systemic intricacies driving the crisis. The qualitative systemic analysis of the crisis revealed the following facts:
\end{abstract}


(i) Various subsystems and elements of the agrarian system (such as soil, farm size, cattle, bees, birds, and friendly bugs) have depleted and the system has been trapped into forty five self-reinforcing vicious loops; (ii) Agrarian system has become investment intensive, synthetic inputs intensive, and dependent on centralized market, credit institutions, laborers, and knowledge for the usage of the synthetic inputs ; (iii) Crops have become vulnerable to the vagaries of climatic conditions, pest attacks, various plant diseases, low soil fertility, and water stresses ; (iv) Agrarian system is subjected to a risk of disproportionate support prices; and (v) Increasing living expenses have further exacerbated the crisis.

Keywords: Agrarian crisis, farmers' suicides, systemic analysis, qualitative system dynamics, Participatory investigation, Vidarbha, India

\section{Introduction}

Since late 1990s, due to the growing indebtedness in agrarian community, farmers' suicides have been hitting the headlines in news media. It took more than 0.1 million reported suicides for its official recognition in year 2004 (Government of India, 2005). Over the span of 18 years (1997-2015), around 0.3 million farmers committed suicide across different parts of India (Sainath, 2014; Wikipedia, 2014; Basu, Das, \& Mishra, 2016). There were 48.6 per cent indebted farmers across India in year 2011 with an outstanding debt of around 25.9 thousand rupees per indebted farmer (Rajeev, Vani, \& Bhattacharjee, 2011). Majorly affected states are Maharashtra, Karnataka, Kerala, and Punjab where the agrarian distress is very high (Reddy \& Mishra, 2009; Kalamkar, 2013; Sainath, 2015). In many parts of India (mainly in the above mentioned states), input prices in agriculture have disproportionally inflated against the support prices that has made agriculture an economically nonviable alternative for a marginal farmer. Mainly small farmers in non-irrigated or semi-irrigated areas that are attempting to earn higher income from farming through heavy investments trapped in the crisis (Reddy \& Mishra, 2009).

The problem of farmers' suicides is just a tip of the iceberg and a much wider, multifaceted, and growing leviathan of agrarian crisis lies at the base. Agriculture had never been subjected to such a crisis of non-viability in the early reported history of India (Suri, 2007). Farmers get trapped in the vicious cycle of crop failure and indebtedness.

Up until now, a set of attempts have been made to understand the causes and impacts of the agrarian crisis. For example, Reddy \& Mishra (2009), Mishra (2006), Mishra (2007), and Dhas (2009) studied the agrarian crisis mainly for policy advocacy to seek state interventions to mitigate the crisis. They analyzed the agrarian reforms, state led interventions since independence, market interventions after globalization, and its impact on the agrarian community. Shroff (2013), Shiva (2007) and Suri (2007) emphasized the inability of the state in regulating the minimum support prices in the wake of WTO free trade policies. Karmarkar (2007) asserted that the inability of the farmers to get access to requisite funds due to imperfections in credit market has been a major cause. Mukherjee (2009) revealed that a number of social, commercial, cultural, and agro-ecological factors and their interlinking are responsible for the crisis. The factors responsible for the crisis include degradation of surface and ground water resources (Ministry of Agriculture, Government of India, 2009; 


\section{Macrothink}

Journal of Agricultural Studies

ISSN 2166-0379

2018, Vol. 6, No. 1

Government of India, 2010), depletion of soil fertility (Reddy \& Mishra, 2009; Chand, 2006; Venugopal, 2004), declining land holding size (Reddy \& Mishra, 2009; Kalamkar, 2013), decline in the growth of agriculture (Sen \& Bhatia, 2004; Bhalla \& Singh, 2009; Ahmad \& Haseen, 2012), increasing vulnerability and agricultural dependence due to mono cropping (Murielle, 2009; Shiva, 2009), dependence of significant part of the labor force on agriculture (Chandramauli, 2011; Kalamkar, 2013), less appropriate Green Revolution technologies for arid and semi-arid regions (Vakulabharanam \& Motiram, 2007), increased dependency on synthetic fertilizers (Altieri, 2009), increase in the cost of fertilizers, seeds, electricity, and water in postmodern reforms (Sen \& Bhatia, 2004; Raghavan, 2008), reduction in the global prices of wheat, cotton, soybean, and rice as a result of the provisions of the agreement on agriculture of World Tread Organization (Shiva, 2009; Suri, 2007), climate change (European Commission, 2009; Zilberman, Liu, Roland-Holst, \& Sunding, 2004), decline in the institutional credit alternatives and institutional support of agriculture (Shetty, 2006; Reddy \& Mishra, 2009; Challa, Joshi, \& Tamboli, 2011), and hefty wedding practices (Sainath, 2007; Tata Institute of Social Sciences, 2005).

It was observed that it is difficult to establish cause and effect relationship for the agrarian distress as it is a very complex process and most of the causes are interrelated. Some of the studies have tried to elaborate the dynamic linkages of a number of factors responsible for the crisis but lacked a comprehensive systemic analysis (Reddy \& Mishra, 2009). The present study focuses on understanding the multifaceted nature of the agrarian crisis by employing a systemic approach (qualitative system dynamics modelling) that takes into account the dynamic linkages between different elements of the agrarian system (Capra, 1996; Sterman, 2010). Participatory field level investigations were carried out in six different villages from three districts in Vidarbha (one of the most affected regions in India). The qualitative systemic synthesis of the agrarian crisis was carried out by dividing the agrarian system into six subsystems. Systemic analysis draws from literature study, participatory investigation of the trends of a number of factors responsible for the crisis, and perception of the participant farmers about the crisis.

\section{Methods}

A system can be regarded as an organized group of a number of elements that interact in certain patterns with each other to produce outcomes. In the present context, farm soil, crops, cattle, insects, birds, water resources, human society, market, and state form a system that is named as an agrarian system. The pressing multidimensional problem of non-viability of this system is called as agrarian crisis. The qualitative systemic approach tries to understand the pattern of complex and non-linear interaction between different elements of the system. This helps to realize the multifaceted aspects of the given problem that has arisen due to the changing state of the number of elements of the system (due to the dynamic nature of the elements) and the pattern of interactions (Sterman, 2010).

Mental database of the people are the biggest sources to know the local realities (Forrester, 1971). Therefore, a qualitative model of the agrarian system was developed by carrying out a set of participatory studies (Chambers, 2008; Honkalaskar, Sohoni, \& Bhandarkar, 2017; Oyo, 
Williams, \& Barendsen, 2009) with a number of selected farmers from six selected villages (by considering the varied availability of the irrigated farmland), namely, Yeulkhed (Buldhana district), Takerkhed Sambhu (Amravati district), Tivsa (Yavatmal district), Pathari (Yavatmal district), Borisinha (Yavatmal district) and Shivni (Yavatmal district) in Vidarbha region of Maharasthra state in India where the farmers are facing acute problems of agrarian crisis. Yavatmal is the most affected district in Vidarbha region (Talule, 2011). Location of these villages is shown in figure 1. A brief agro-sociological background of these villages is listed in table 1. It was ensured that the discussion groups would comprise farmers of different age groups, land holding, and social background. Visual maps, temporal graphs, and tabulated data-sheets generated during the activity were shared and discussed with the farmers for their further refinement and triangulation.

The systemic approach (Coyle, 2000; Oyo, Williams, \& Barendsen, 2009; Pruyt, 2013; Sterman, 2010) adopted in the present study to devise a qualitative system dynamics model of the agrarian system in order to understand the dynamic complexity of the agrarian crisis includes the following steps.

\subsection{Identification of a Set of Important Factors of the Agrarian System}

An investigation of the published literature on agrarian crisis and perceptions of the participant farmers (from the six selected villages) elicited through a set of participatory exercises revealed a number of important factors responsible for the crisis.

\subsection{Finding out Trends of the important factors}

Trends or reference modes (Sterman, 2010, Saeed, 1998) of the important factors of the agrarian system were documented with the farmers in the six villages to find out patterns of variation or change of these factors. The selected time horizon started from year 1995 (when there was no crisis) till year 2015.

\subsection{Developing stock and flow diagrams of the agrarian subsystems}

Stock and flow diagrams (elaborated in appendix A, these depict feedback structures of the crisis) of a total of six assumed subsystems (indebtedness, land fertility, water table, cattle population, farm size, and human population) were developed by finding out various reasons for the variation of the important factors over the chosen time horizon. These diagrams revealed various endogenous factors (dependent on the other factors of the system) and exogenous factors (independent on any other factor of the system) responsible for the crisis.

\subsection{Identification of the reinforcing or vicious loops in the system}

Stock-flow diagrams revealed a number of reinforcing loops or vicious cycles in the subsystems. These vicious cycles disclosed the causes behind the depleting agrarian system.

The trends, participant farmers' perceptions for the reasons behind the trends, various reasons elaborated in the published literature, and regular reflections of the farmers formed the basis to develop a qualitative systemic model of the agrarian crisis. The qualitative systemic models of the agrarian system were refined by an iterative process of discussions with 


\section{Macrothink}

Journal of Agricultural Studies

ISSN 2166-0379 2018, Vol. 6, No. 1

farmers and investigation of the literature.

Apart from the qualitative systemic model, details of an average income and expense incurred during the cultivation of cotton and soybean with pigeon pea as an intercrop were documented to find out the distribution of the expenses among various inputs and the efficacy of the cultivation practices to earn the farmers' livelihood.

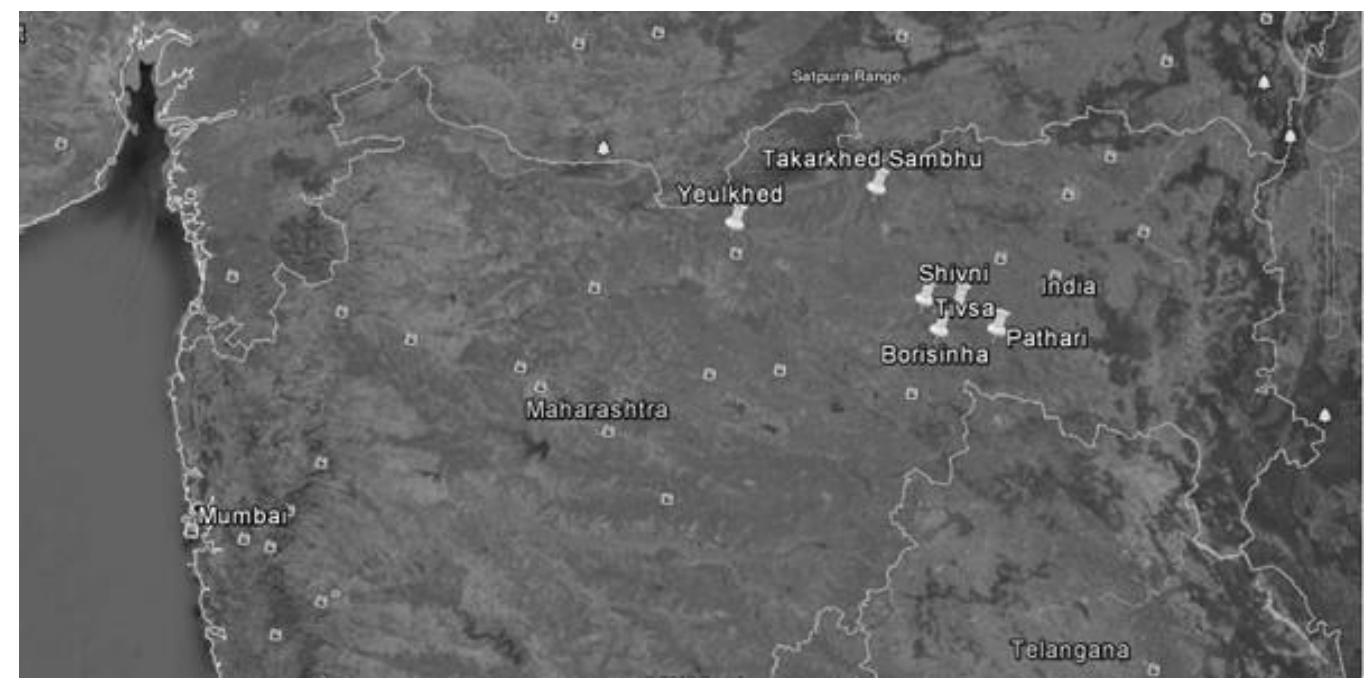

Figure 1: Location of six selected villages in Vidarbha region, Maharashtra, India

The following section elaborates outcomes of the participatory microscopic study that was undertaken to build a systemic understanding of the crisis. 
Table 1: List of sociological and agrarian factors of the selected villages

\begin{tabular}{|c|c|c|c|c|c|c|}
\hline Particulars & Yeulkhed & $\begin{array}{l}\text { Takarkhed } \\
\text { Sambhu }\end{array}$ & Tivsa & Pathari & Borisinha & Shivni \\
\hline Population & 1155 & 5800 & 3324 & 2460 & 1539 & 855 \\
\hline $\begin{array}{l}\text { Number of } \\
\text { households } \\
\text { (Caste-wise } \\
\text { break-up) }\end{array}$ & $\begin{array}{l}233 \\
(\mathrm{SC}-30 \%, \\
\mathrm{ST}-0 \%, \\
\text { OBC-53.2\%, } \\
\mathrm{NT}-11.6 \%, \\
\text { Open - } \\
5.2 \%)\end{array}$ & $\begin{array}{l}984 \\
(\mathrm{SC}-19.3 \%, \\
\text { ST }-4.1 \%, \\
\text { OBC-74.6\%, } \\
\text { Open-2\%) }\end{array}$ & $\begin{array}{l}752 \\
(\mathrm{SC}-14.28 \%, \\
\text { ST }-15 \%, \\
\text { OBC-25\%, } \\
\text { SBC-10\%, NT- } \\
30 \%, \text { Open - } \\
2.6 \%)\end{array}$ & $\begin{array}{l}456 \\
(\mathrm{SC}-15.4 \%, \\
\mathrm{ST}-39.5 \%, \\
\text { OBC-11\%, VJ } \\
-30.7 \%, \text { Open } \\
-3.3 \%)\end{array}$ & $\begin{array}{l}385 \\
(\mathrm{SC}-14.28 \%, \mathrm{ST} \\
-15 \%, \\
\text { OBC-25\%, } \\
\text { SBC-10\%, NT- } \\
30 \%, \text { Open - } \\
2.6 \%)\end{array}$ & $\begin{array}{l}160(\mathrm{SC}-18.75 \%, \\
\mathrm{ST}-6.25 \%, \\
\mathrm{OBC}-43.75 \%, \\
\mathrm{SBC}-31.25 \%)\end{array}$ \\
\hline $\begin{array}{l}\text { Number of } \\
\text { farmers' } \\
\text { households }\end{array}$ & 168 & 648 & 451 & 282 & 215 & 90 \\
\hline $\begin{array}{l}\text { Land } \\
\text { holding } \\
\text { estimates (\% } \\
\text { of farmers) }\end{array}$ & $\begin{array}{l}32 \% \leq 2 \text { ha, } \\
2 \text { ha }<48 \% \\
\leq 4 \text { ha, } \\
20 \%>4 \text { ha }\end{array}$ & $\begin{array}{l}7.4 \% \leq 2 \text { ha, } \\
2 \text { ha }< \\
38.6 \% \leq 4 \\
\text { ha, } \\
54 \%>4 \text { ha }\end{array}$ & $\begin{array}{l}70 \% \leq 2 \mathrm{ha}, \\
2 \mathrm{ha}<18 \% \leq 4 \\
\text { ha, } \\
12 \%>4 \text { ha }\end{array}$ & $\begin{array}{l}50 \% \leq 2 \text { ha, } \\
2 \text { ha }<45 \% \leq \\
4 \text { ha, } \\
5 \%>4 \text { ha }\end{array}$ & $\begin{array}{l}40 \% \leq 2 \text { ha, } \\
2 \text { ha }<40 \% \leq \\
4 \text { ha, } \\
20 \%>4 \text { ha }\end{array}$ & $\begin{array}{l}55.6 \% \leq 2 \text { ha, } \\
2 \text { ha }<33.3 \% \leq 4 \\
\text { ha, } \\
11.1 \%>4 \text { ha }\end{array}$ \\
\hline $\begin{array}{l}\text { Availability } \\
\text { of irrigated } \\
\text { water for the } \\
\text { total } \\
\text { farmland }\end{array}$ & Around 5\% & Around $25 \%$ & Around $70 \%$ & Around 9\% & Around $60 \%$ & Around $30 \%$ \\
\hline $\begin{array}{l}\text { Indebted } \\
\text { farmers }\end{array}$ & $>97 \%$ & $>70 \%$ & $>95 \%$ & $>98 \%$ & $>90 \%$ & $>95 \%$ \\
\hline $\begin{array}{l}\text { People's } \\
\text { perception } \\
\text { of a village } \\
\text { specific } \\
\text { major } \\
\text { problem } \\
\text { other than } \\
\text { indebtedness }\end{array}$ & $\begin{array}{l}\text { Rain fed } \\
\text { agriculture } \\
\text { mainly due } \\
\text { to the high } \\
\text { salinity of } \\
\text { the ground } \\
\text { water }\end{array}$ & $\begin{array}{l}\text { Paucity of } \\
\text { irrigated } \\
\text { water due to } \\
\text { the high } \\
\text { salinity of } \\
\text { the ground } \\
\text { water }\end{array}$ & $\begin{array}{l}\text { Lack of } \\
\text { laborers' } \\
\text { availability due } \\
\text { to the } \\
\text { availability of } \\
\text { the alternative } \\
\text { wage labor } \\
\text { work in } \\
\text { Yavatmal town } \\
\text { that is located } \\
\text { at } 8 \mathrm{~km} \text { away } \\
\text { from the village }\end{array}$ & $\begin{array}{l}\text { Vulnerable } \\
\text { crop yield due } \\
\text { to the rain fed } \\
\text { agriculture }\end{array}$ & $\begin{array}{l}\text { Flood in a local } \\
\text { river destroys } \\
\text { the crop and soil } \\
\text { fertility } \\
\text { frequently }\end{array}$ & $\begin{array}{l}\text { Vulnerable crop } \\
\text { yield and wild } \\
\text { animal attacks on } \\
\text { the farm from the } \\
\text { surrounding } \\
\text { forest area }\end{array}$ \\
\hline $\begin{array}{l}\text { Credit } \\
\text { alternatives }\end{array}$ & & & & & & y lenders \\
\hline
\end{tabular}


This table represents preliminary sociological background and a few agrarian details of the selected villages. In caste-wise break up, the meanings of various abbreviations are as follows: SC - scheduled castes, ST - scheduled tribes, OBC - Other backward castes, SBC - special backward castes, NT - Nomadic tribes, VJ - vimukt jati (de-notified tribes), and Open - non backward castes. Land is measured in hectares (ha).

\section{Field Level Investigation}

The trends or reference modes of various important factors responsible for the crisis are elaborated below.

\subsection{Crop Pattern}

Crop pattern has shifted from cotton to soybean (with pigeon pea as an inter-crop in both the crops) as a major crop over the past two decades due to the increased cost of production of cotton (associated mainly with labor, fertilizers, pesticides, and seeds) and proportionately lesser increase in its selling price (see figure 2). Secondly, vagaries of weather, vulnerability of crop varieties to various pest attacks, and inadequate irrigation facilities have also made the yield unreliable. The problems of frequent wild animal attacks on sorghum and sunflower has reduced their area under cultivation. Due to the reduction in the cattle count, farmers reduced the cultivation of sorghum in monsoon that provides fodder.

\subsection{Fertilizers, Pesticides, and Seed Prices}

Reduction in the subsidies given by the State for fertilizers, pesticides, and seeds along with the rising inflation (Sainath, 2007; Reddy \& Mishra, 2009; Dhas, 2009; Mishra, 2006) led to their prices blowing up as shown in figures 3 (a), 3(b), 3 (c), and 3(d). The price of fertilizer (Di-ammonium phosphate) has escalated six folds from year 1995 to 2013. Whereas, pesticides and seeds prices increased by around 3-5 times and 5-6 times respectively during this period.

\subsection{Requirement of Fertilizers}

Adoption of the Green Revolution technologies to arid and semi-arid areas by farmers without suitable changes has resulted in the deterioration in the land fertility. The key reasons are soil erosion, change in the soil acidity, addition of toxic elements, negative effect on the microbiological activities in the soil due to excessive use of chemical fertilizers (Suzuki, 2003; Setboonsarng, 2006; Ashiya \& Rathore, 2014; Savci, 2012), monotonous extraction of a particular type of nutrients from soil due to mono-cropping, reduction of organic carbon in the soil due to the drastic reduction in the usage of manure fertilizers, and excessive irrigation (Reddy \& Mishra, 2009; Dhas, 2009; Roy, 2006; Prasanna, 2013). This has increased the demand of fertilizers by four to six times as shown in figure 3 (e). Figure 3 (e) represents the fertilizer requirement ( $\mathrm{Di}$ ammonium phosphate) for cotton crop (with pigeon pea as inter crop) other than Takerkhed Sambhu (where mainly soybean is cultivated).

\subsection{Requirement of Pesticides}

Mono cropping and reduction in the natural predators of various pests (such as birds and 
some insects) due to the extensive usage of pesticides increased certain pests (Shetty, 2004; Berg, 2001). Further vulnerability of the high yielding and hybrid crops to the local pests and development of pesticide resistance forced farmers to use increased quantity of modified pesticides at high cost (Huang, Pray, \& Rozelle, 2002) (see figure 3 (b) and 3 (f)). Figures 3 (b) and 3 (f) represent the pesticide usage for cotton crop (with pigeon pea as inter crop) for the villages other than Takerkhed Sambhu (where mainly soybean is cultivated).

\subsection{Labor Wages}

Labor wages have escalated by around eight to nine times in Yeulkhed and Shivni and by around fifteen to nineteen times in Takarkhed Sambhu, Tivsa, Pathari, and Borisinha (see figure $4(a))$.

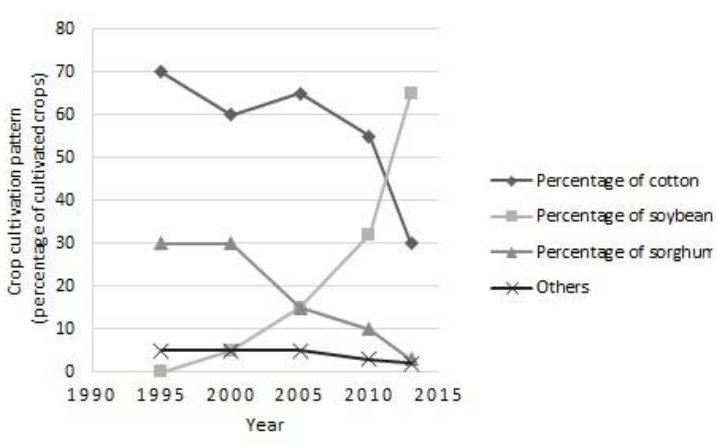

a) Yeulkhed

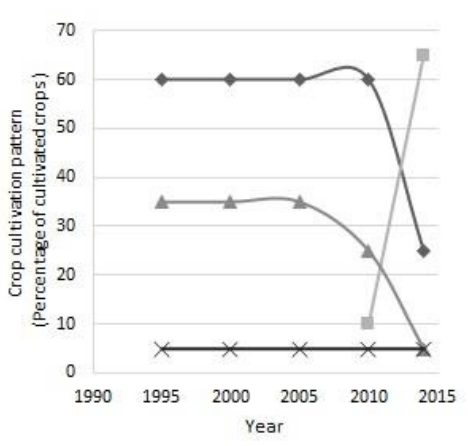

c) Tivsa

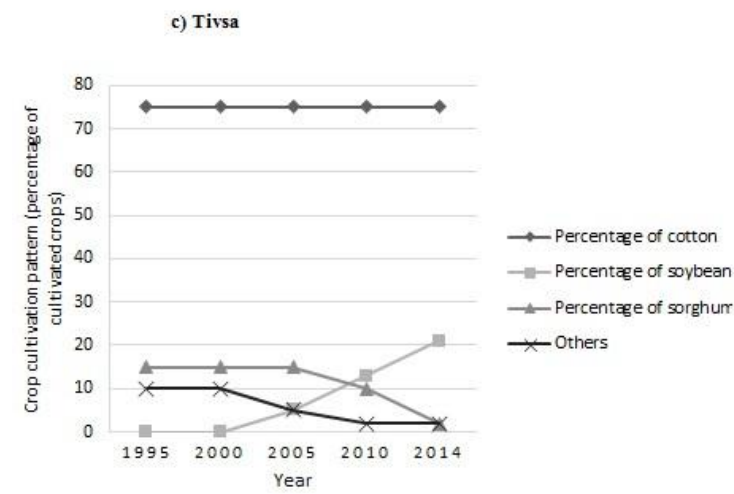

e) Borisinha
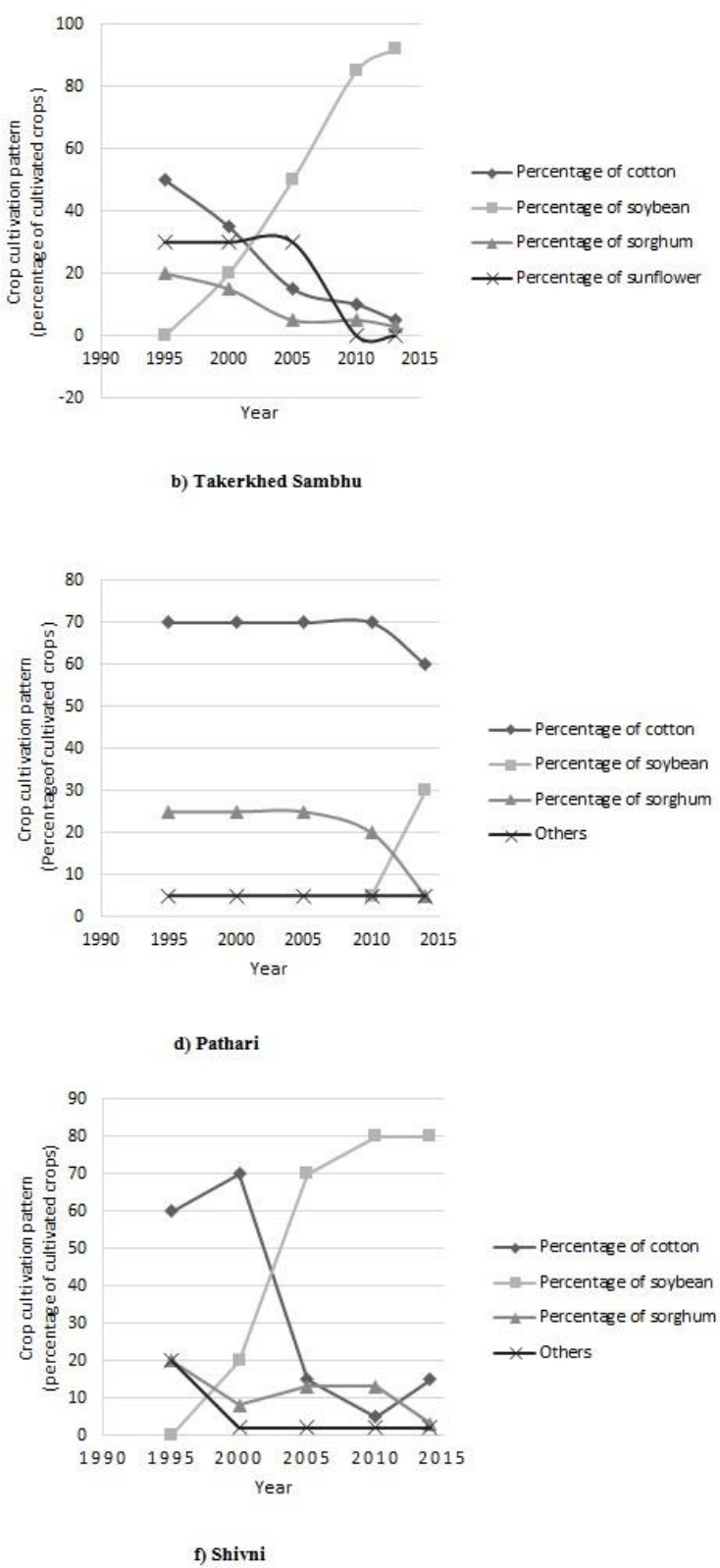

Figure 2: Variation of crop pattern in the six villages over the past two decades 


\section{Mll Macrothink}

Journal of Agricultural Studies

ISSN 2166-0379

2018, Vol. 6, No. 1

The reasons given by the farmers are as follows: (i) Reduced family size has reduced (see figure 4 (b)) the total number of human work hours available per household to cultivate the respective farm. This has increased the demand for labor; (ii) Skewed implementation of the employment guarantee scheme of the State Government has increased labor cost at some places.

For example, tree plantation and conservation drive by social forestry department through employment guarantee scheme paid 150 rupees to laborers for a day near Takerkhed Sambhu village. In reality the people worked for just 3 hours a day instead of 8 hours and received the complete wages. Such practices increased labor charges. Berg, Bhattacharyya, Durgam, \& Ramachandra (2012), Imbert \& Pappa (2013), and Azam (2012) have also inferred that the employment guarantee scheme has inflated the labor wages; (iii) People get more wages in the non-agricultural businesses; and (iv) Certain percent of the families of land laborers have acquired a comparatively more secured non-agricultural livelihood alternative and migrated to nearby cities. This has also reduced the labor pool and thus increased the demand for wage labor work and thus the labor cost.

\subsection{Yield}

Average yield per hectare of cotton has escalated mainly after the advent of genetically modified varieties (BT cotton) as shown in figure 4 (c). It has slightly declined after 2010 at many places. Input costs and vulnerability of crop to the vagaries of nature have also increased. The average yield per acre of soybean crop has escalated during initial years after its inception. However, at all the places it has reduced recently (see figure $4(\mathrm{~d})$ ). The reasons are increased pest attacks, reduction in the land fertility, and sporadic rain. Here, figures 4 (c) and 4 (d) represent the farmers' perceptions about average yields of the major cultivation practice in the village (either rain-fed or irrigated farming, refer table 1).

\subsection{Support/market Prices}

The support price for cotton has increased by three to four times since year 1995 (see figure 4 (e)). Similarly, the market price of soybean has increased by around three and half times since 2000 (see figure 4 (f)). The process that determines the support prices does not take into account the context specificity. Thus it makes agriculture nonviable in some contexts that lack timely provision of various resources. Secondly, the farmers recognize the support prices only at the end of the cultivation period. Thus a farmer cannot predict the support price in advance and thus cannot line up the expenses accordingly.

\subsection{Farm Size}

Increase in the population and division of families reduced the average farm land per household by around three times over the past two decades as shown in figure 5 (a). This has reduced the average yield per household.

\subsection{Cattle Population}

Cattle population (bullocks, cows, and buffaloes) has declined as shown in figures 5 (b) and 5(c). The reasons listed by the farmers are as follows: (i) Fodder availability has reduced due 
to the shift in the crop pattern, reduction in the hay fields (hay fields are converted in to the farms), and increasing usage of herbicides to kill the farm weeds; (ii) Reduction in the family size reduced the household capacity to rear the cattle; (iii) Increase in the labor wages; (iv) Availability of tractors to plough the fields; (v) Farmers sold cattle to support day to day household expenses or intermittent large scale expenses such as wedding; and (vi) Deterioration of the health of cattle due to the consumption of fodder and water contaminated by pesticides and chemical fertilizers.

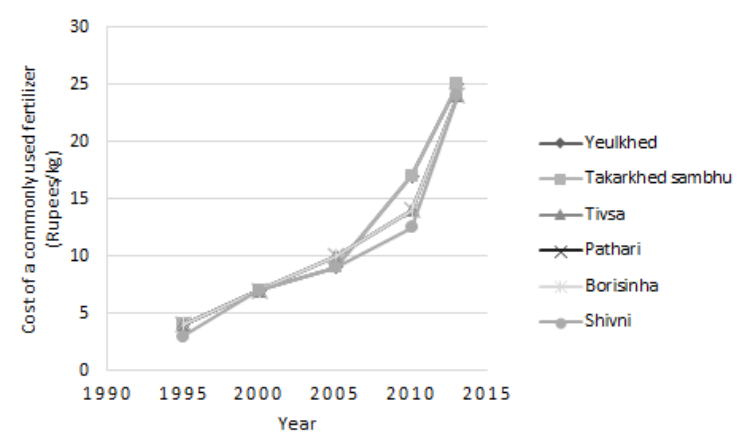

(a) Variation of fertilizer price

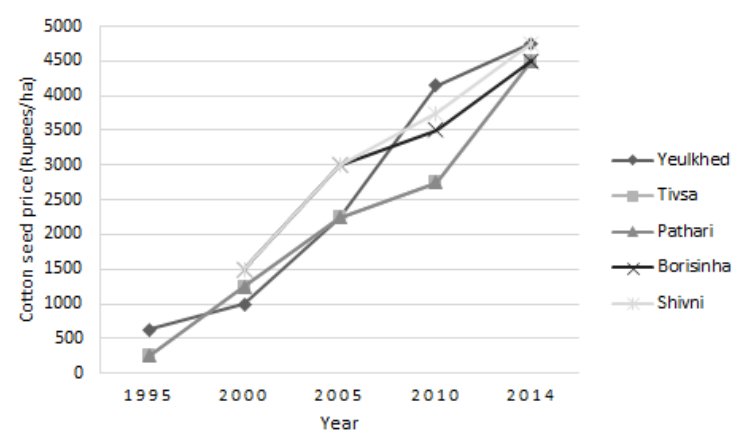

(c) Variation of cotton seed price

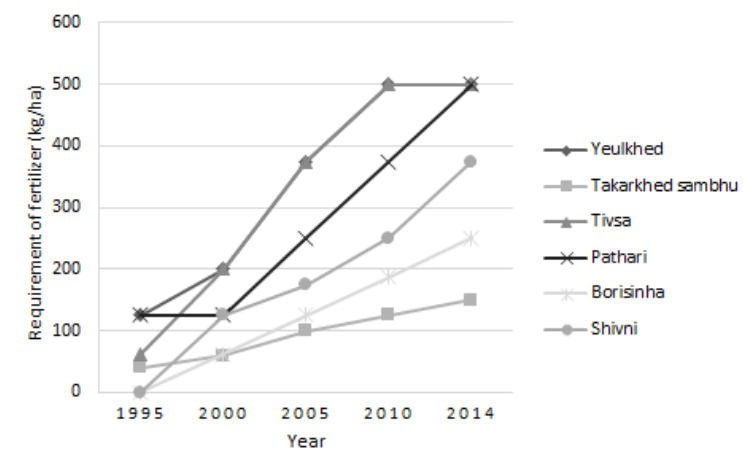

(e) Increase in the requirement of fertilizers (DAP)

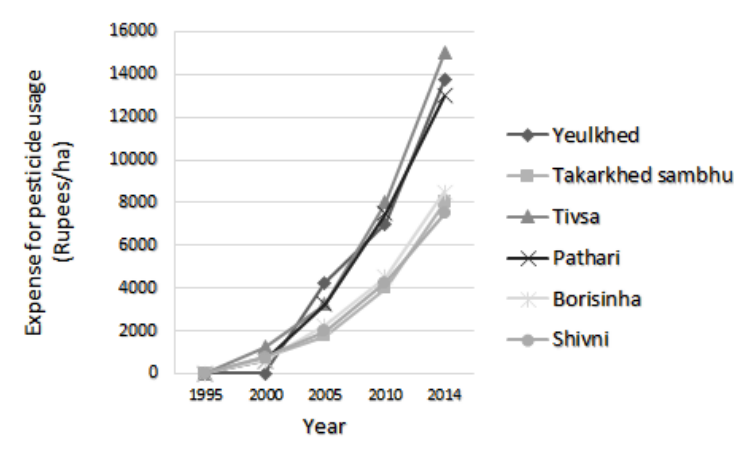

(b) Increase in the expense of pesticides

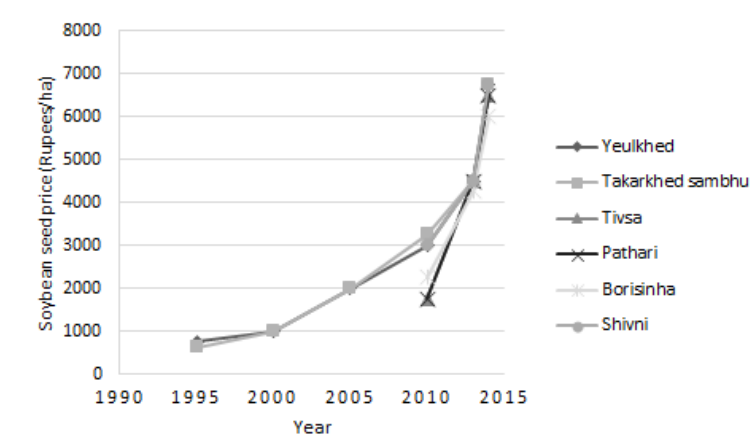

(d) Variation of soybean seed price

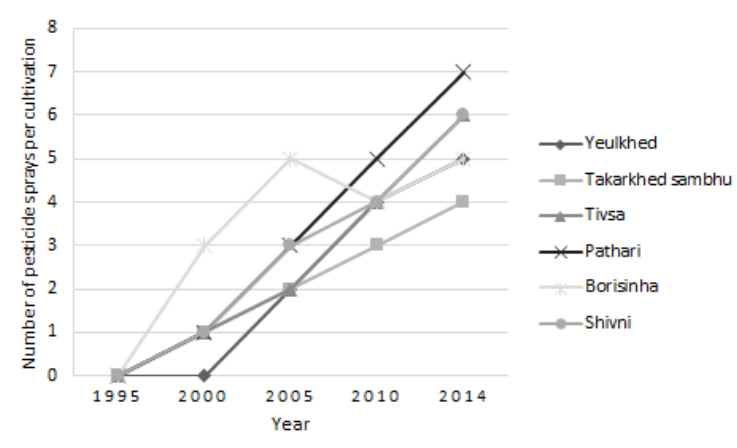

(f) Increase in the demand of pesticides

Figure 3: Variation of various inputs over the period of two decades 


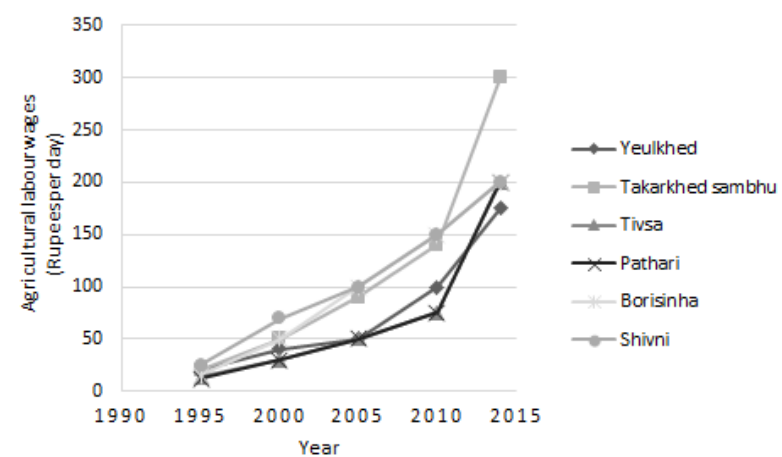

(a) Increase in the labor wages in the past two decades

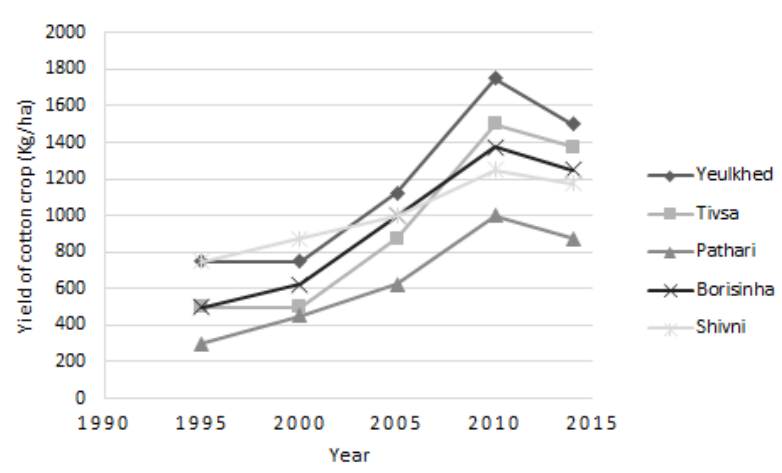

(c) Changes in the yield per acre of cotton

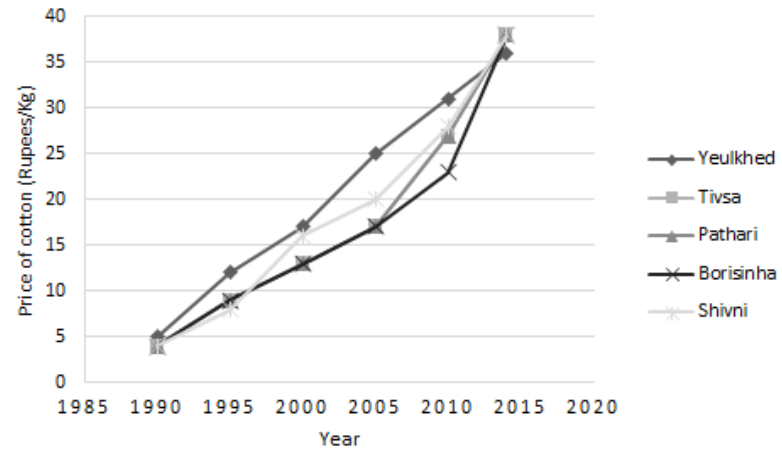

(e) Increase in the support price of cotton

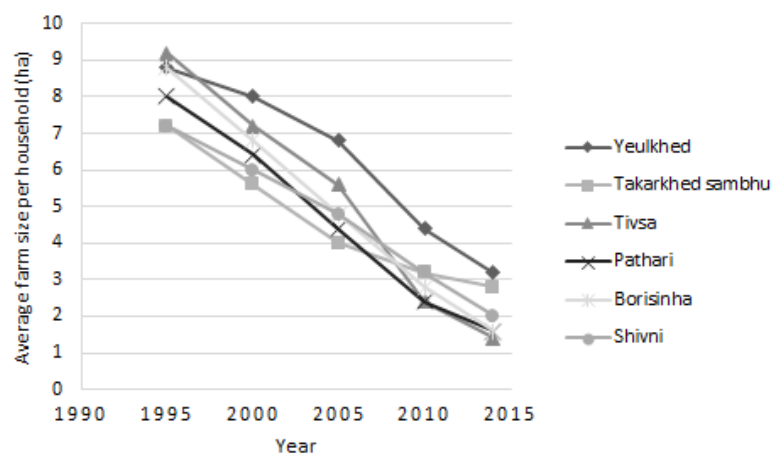

(b) Reduction in the average family size in the past two decades

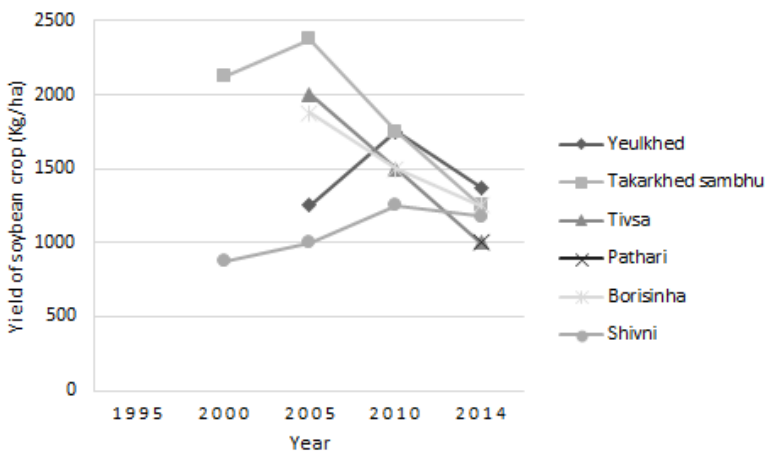

(d) Changes in the yield per acre of soybean

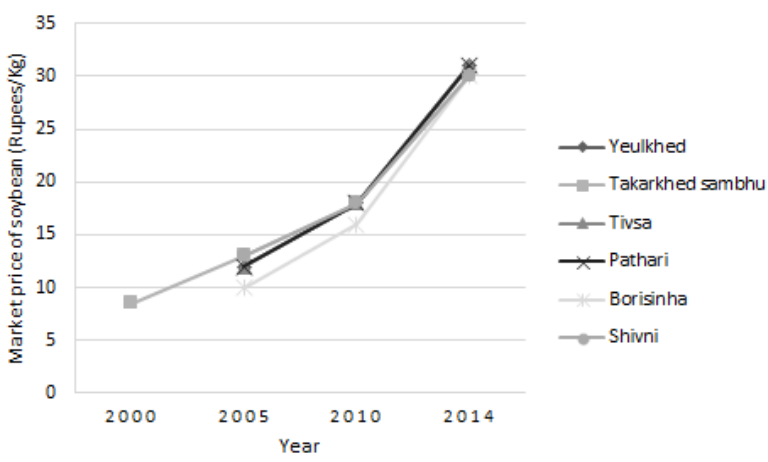

(e) Increase in the market price of soybean

Figure 4: Variation of various elements of the agrarian system over the period of two decades

This has increased the total cost of rearing the cattle. Reduction in the cattle population reduced the input of manure fertilizers to the soil and that has reduced the organic carbon and humus in the soil. 


\section{Macrothink}

Journal of Agricultural Studies

ISSN 2166-0379

2018, Vol. 6, No. 1

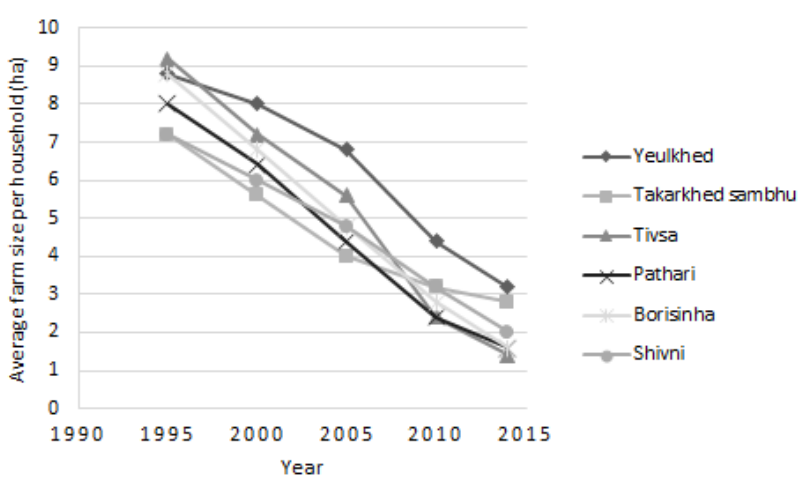

(a) Reduction in the farm size per household

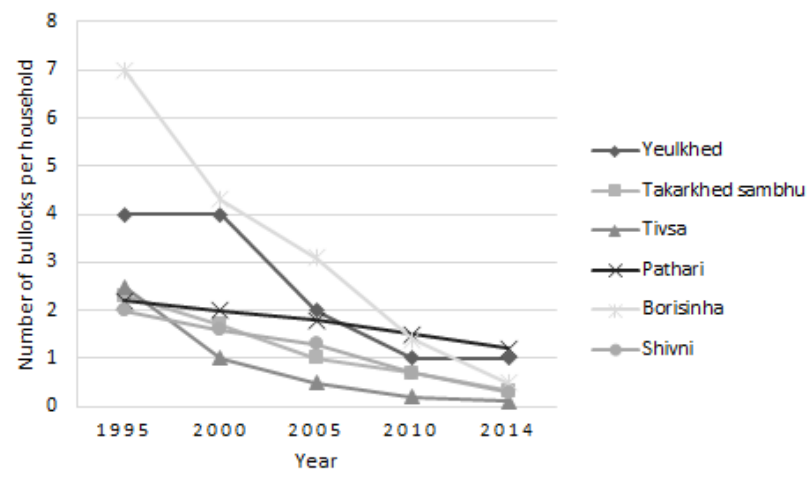

(b) Reduction in number of bulls owned by a household

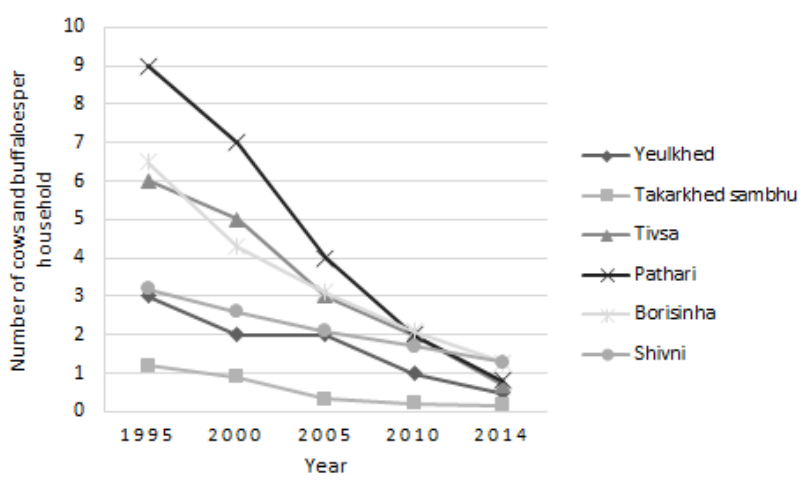

(c) Reduction in number of cows and buffaloes

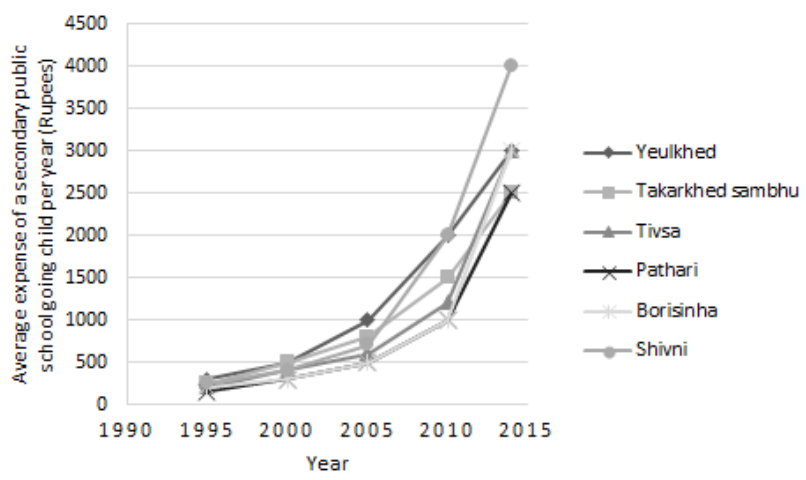

(d) Increase in the expenses in public schools owned by a household

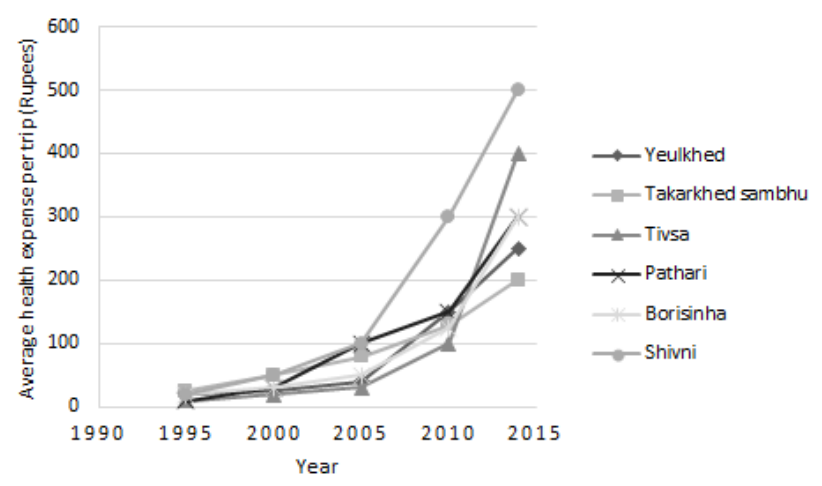

(e) Increasing trend of health expenses per consultation to doctors

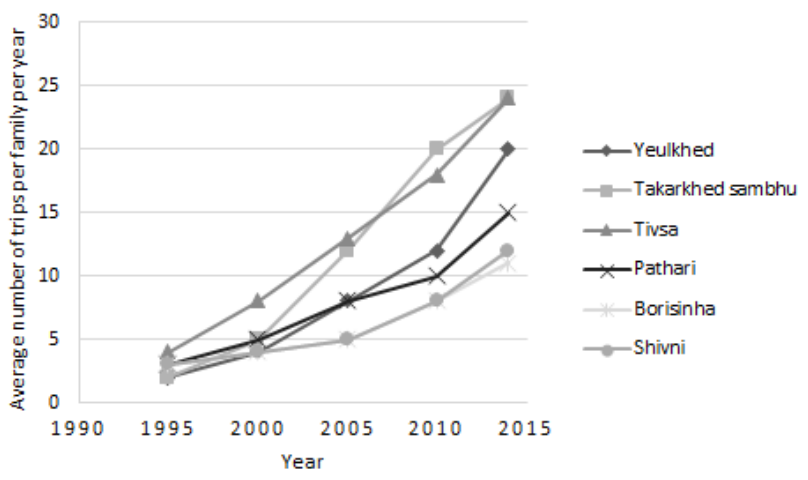

(f) Increasing number of consultations of doctors per year

Figure 5: Variation of various elements related to the agrarian system over the period of two decades

\subsection{Reduction in the Population of Birds and Friendly Insects}

Extensive usage of pesticides have poisoned birds and friendly insects that feed on pests (Katole, Kumar, \& Patil, 2013; Kohler \& Triebskorn, 2013; Boatman et al., 2004; Gregory, David, Noble, \& Custance, 2004; Huang, Pray, \& Rozelle, 2002). Apart from this fact, contamination of surface water sources by pesticides has also reduced the population of birds and insects. Reduction in these natural predators of pests increased the population of pests, 
thereby increasing the demand for pesticides and further deterioration of the population of birds and insects. Reduction in birds' population also reduced the natural introduction of the manure from birds' excreta to the soil.

\subsection{Reduction in Bees}

Thinning of the forests, mono cropping, deterioration of the surface water sources, and extensive usage of pesticides (Henry et al., 2012; Whitehorn, OConnor, Wackers, \& Goulson, 2012; Krupke, Hunt, Eitzer, Andino, \& Given, 2012) have reduced the population of bees. It has affected the process of pollination, thereby the yield.

\subsection{Expense for School Education}

The average school expenditure has increased by around six to eight times as shown in figure 5 (d). Commercialization of education in the rural area has led to an additional increase in the expense on education. Farmers feel that the quality of education in the public schools has deteriorated. So they prefer to send their children to private schools. In late nineties, public school teachers lived in the villages. This had upheld the quality of education. However, since last two decades, teachers started living in the nearby towns and could pay lesser attention to the students as compared to the earlier time. Secondly, due to the agrarian crisis, farmers aspire that their children should get good education so that they can generate livelihood in the non-farm sector. Thus farmers are keen on sending their children to private schools.

\subsection{Health Expenses}

The changing lifestyle, shift in the diet pattern, and increased addiction have resulted in the deterioration of the health of rural people (Singh, 2011; Chauhan \& Aeri, 2013). Public health systems are almost defunct and this situation has forced the farmers to opt for the costly commercial services. The farmers reported that there has been a reduction in the skin diseases in all the six villages. However, various communicable diseases such as tuberculosis, typhoid, and chikungunya have become prevalent. Kidney stone, joint pain, diseases related to the digestive system have also increased. Commercialization of health services and escalated health related problems have inflated the health expenses as shown in figures 5 (e) and 5 (f).

\subsection{Wedding Expenses}

Due to the increase in inflation, dowry, and the number of activities carried out in a wedding, there is an increasing trend of expenditure on wedding (see figures 6 (a) and 6 (b)). The figures show the average trends of socially forward communities. The respective trends for the socially backward communities are similar with less magnitudes. Dowry has recently inflated mainly because of the inflated price of gold. Wedding ceremony imposes a sharp rise in the economic distress for a marginal farmer in this region.

\subsection{Liquor Rates}

Liquor addiction has increased over the last decade. Technology interventions in the field of human entertainment (such as television and mobile phones), domestic activities, and livelihood activities have reduced the group (or community level) activities, thereby reducing 


\section{Macrothink Institute ${ }^{\mathrm{TM}}$}

the social cohesion and thus abidance to the social norms. This has led to an increase in the liquor addiction. Increase in the indebtedness also leads a farmer to get succumbed to the addiction in order to get rid of the distress for a while. Over the last fifteen years, the liquor price per liter has increased by around 12 times, mainly due to inflation. Liquor addiction is also an invitation to a number of health problems and in turn to the indebtedness. An indebted farmer succumbing to the liquor addiction further aggravates the problem.

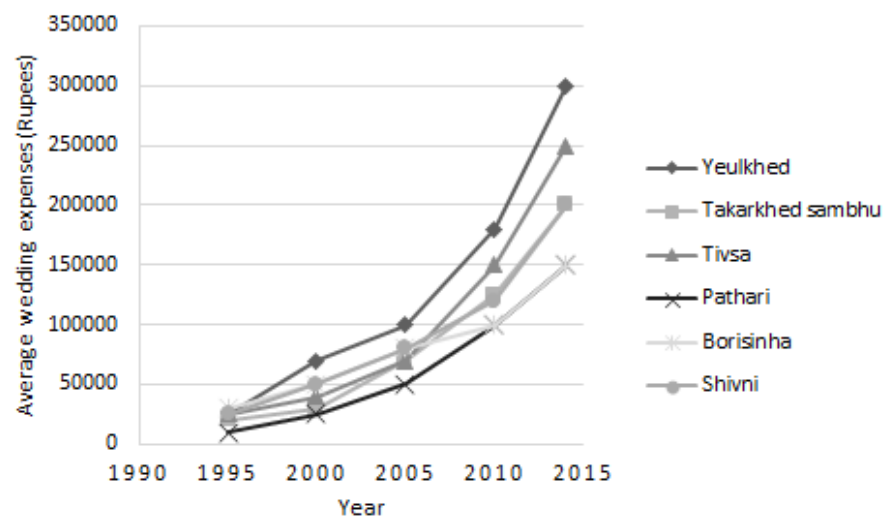

(a) Increasing average expenditure on weddings

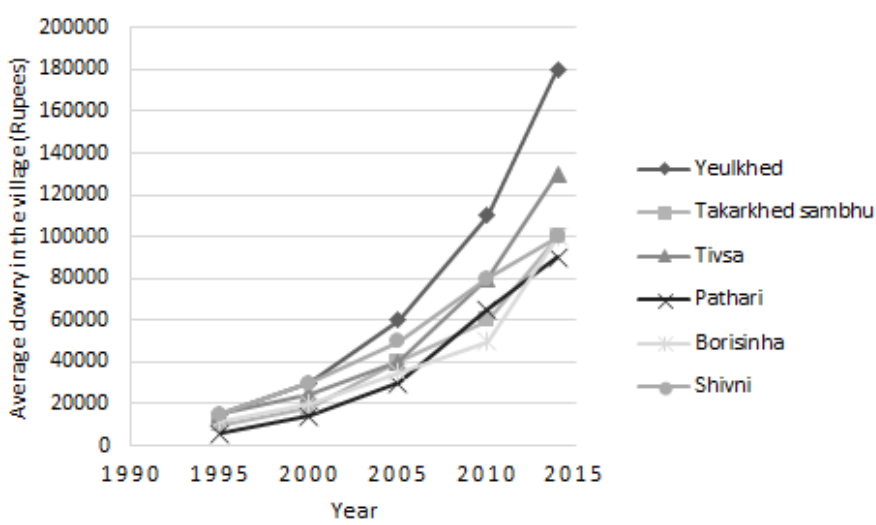

(b) Increasing trend of dowry in a wedding

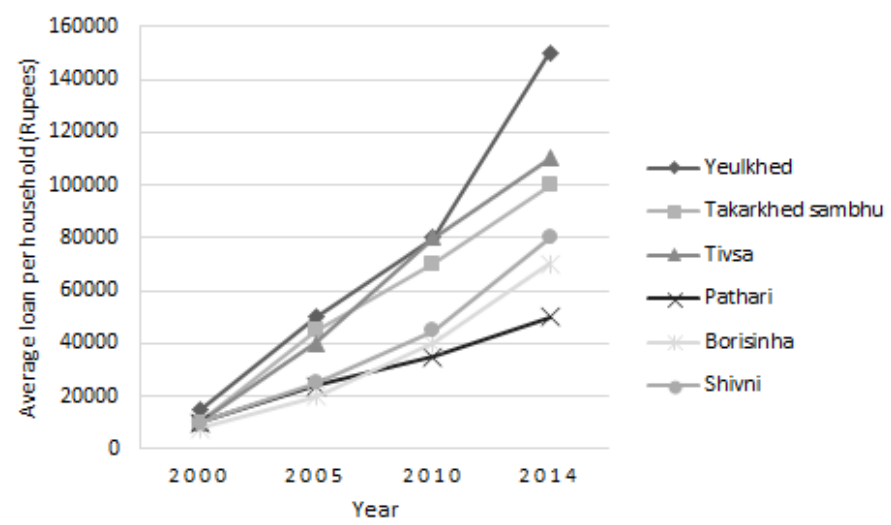

(c) Increasing indebtedness of an average farmer

Figure 6: Variation of various elements related to the agrarian system over the period of two decades

\subsection{Electricity Price}

Household electricity bill has increased over the last decade by around four times (from an average bill of around 60 rupees per month to around 250 rupees per month). Whereas, farm electricity bill has increased from 1200 rupees per year in 2004 to 3600 rupees per year in 2010 and to 6000 rupees per year in 2014 for a $3 \mathrm{hp}$ electric pump (for Tivsa, Pathari, 
Borisinha, and Shivni).

\subsection{Indebtedness}

Increasingly investment intensive agriculture (Raghavan, 2008), uncertain yields, inadequate support prices, and increased cost of living has increased the indebtedness of an average farmer as shown in figure 6 (c). Although the amount of loan offered from a secured and regulated credit sources has increased over the last ten years, it is not adequate when a farmer faces consecutive crop failures and finally opts for unregulated credit sources. Interest rates levied by the local money lenders are in the range of 3 per cent to 10 per cent per month. It is very easy to get loan from a moneylender. Whereas, it is a very difficult task to get a loan from a nationalized bank on a required time-line due to the tedious paper work. Farmers also complained that they have to bribe many Government officials to get required documents to sanction a loan. This again increases the economic load on a farmer. The farmers observed that there is an increasing trend of bribery.

Details of the average expense incurred in various agricultural activities (including labor charges) and average total income for cotton and soybean crops with pigeon pea as an inter-crop are listed in tables 2 and 3 respectively. The column, 'particulars' (in tables 2 and 3) include labour work as well for each mentioned activity. It can be observed that pesticide application (insecticides and herbicides), fertilizers application, and seeds cover most of the total expense. Average share of labor charges in the total expense is around $46.9 \pm 12.2$ per cent (at the statistical significance level of 0.05) for cotton cultivation and is around $31.1 \pm$ 11.4 per cent (at the statistical significance level of 0.05 ) in case of soybean cultivation. Share of the expense on the items procured from the local market (seeds, fertilizers, insecticides, pesticides, tonics, and diesel for tractor) and labor charges in the total expense is around 90.8 \pm 4.9 per cent (at the statistical significance level of 0.05 ) for cotton cultivation and is around $79.5 \pm 3.9$ per cent (at the statistical significance level of 0.05 ) for soybean cultivation. Average profit from cotton and soybean cultivations are 13153 and 18240 rupees per hectare respectively. Average profits for rain fed cultivation of cotton and soybean are 9340 and 16 862 rupees per hectare respectively. Average land holding in Vidarbha region was 2 ha per household in 2003 (Mishra, 2009). Thus rain fed cultivation of cotton is not an economically viable alternative. Other than farming, marginal farmers in Vidarbha who do not have other livelihood alternatives also work as a land laborer.

The trends of the usage of various items procured from the local market, labor wages, and family size reflect a trend of substantial escalation in the total investment on agriculture over the last two decades. The trends of requirement of fertilizers and insecticides, cattle population, population of birds, friendly insects and bees, and farm size show depletion of various agricultural subsystems. Similarly, the trends of expense over healthcare and education, liquor addiction, and wedding practices show escalation in the total expense for living. These trends have challenged the potential of agriculture to support the living of the farming community.

The problem of Agrarian crisis has grown in multiple directions over a couple of decades. Many key factors associated with agriculture have undergone both qualitative and 
quantitative changes over this period. There exist non-linear and dynamic relationships among various factors that determine the trends of the agrarian system. Thus the problem is dynamic in nature and demands a systemic analysis for its better understanding. The following section would attempt to interlink these various factors to develop an understanding of the dynamic complexities of the agrarian crisis.

Table 2: Total average expense and income for various selected villages for cotton and pigeon pea

\begin{tabular}{|c|c|c|c|c|c|c|c|c|c|c|}
\hline \begin{tabular}{l|} 
Serial \\
number
\end{tabular} & Particulars & $\begin{array}{l}\begin{array}{l}\text { Yeulkhed } \\
(\mathrm{Ru}- \\
\text { pees/ha })\end{array} \\
\end{array}$ & $\begin{array}{l}\text { Tivsa } \\
\text { (Rain } \\
\text { fed } \\
\text { farm) } \\
(\mathrm{Ru}- \\
\text { pees/ha) }\end{array}$ & $\begin{array}{l}\text { Tivsa } \\
\text { (Irri- } \\
\text { gated) } \\
(\mathrm{Ru}- \\
\text { pees/ha) }\end{array}$ & $\begin{array}{l}\text { Pathari } \\
(\mathrm{Ru}- \\
\text { pees/ha) }\end{array}$ & $\begin{array}{l}\text { Borisinha } \\
\text { (Rain } \\
\text { fed } \\
\text { farm) } \\
(\mathrm{Ru}- \\
\text { pees/ha) }\end{array}$ & $\begin{array}{l}\text { Shiivni } \\
\text { (Rain } \\
\text { fed } \\
\text { farm) } \\
(\text { Ru- } \\
\text { pees/ha) }\end{array}$ & $\begin{array}{l}\text { Shivni } \\
\text { (Irrigated } \\
\text { farm) } \\
\text { (Ru- } \\
\text { pees/ha) }\end{array}$ & $\begin{array}{l}\text { Average } \\
\text { expense } \\
\text { for each } \\
\text { activity } \\
\text { (Ru- } \\
\text { pees/ha) }\end{array}$ & $\begin{array}{l}\text { Percentage } \\
\text { of total } \\
\text { expense }\end{array}$ \\
\hline 1 & $\begin{array}{l}\text { Ploughing and } \\
\text { cleaning }\end{array}$ & 3500 & 5000 & 6250 & 3750 & 4500 & 5000 & 5000 & 4714 & 6.50 \\
\hline 2 & Sowing pigeon pea & 1500 & 1500 & 1500 & 500 & 1500 & 750 & 750 & 1143 & 1.58 \\
\hline 3 & Sowing cotton & 5000 & 5000 & 5000 & 4500 & 5000 & 6000 & 6000 & 5214 & 7.19 \\
\hline 4 & Fertilizers & 8250 & 21250 & 32500 & 7500 & 12000 & 13000 & 18750 & 16179 & 22.32 \\
\hline 5 & Tilling & 4500 & 7500 & 12500 & 1500 & 4000 & 10000 & 10000 & 7143 & 9.85 \\
\hline 6 & $\begin{array}{l}\text { Weeding/herbicides } \\
\text { spraying }\end{array}$ & 6000 & 7500 & 7500 & 5000 & 10000 & 10000 & 10000 & 8000 & 11.04 \\
\hline 7 & Insecticides & 11250 & 12750 & 17500 & 13000 & 8500 & 7500 & 11500 & 11714 & 16.16 \\
\hline 8 & Cotton Plucking & 7500 & 7500 & 15000 & 5250 & 6250 & 7500 & 10500 & 8500 & 11.73 \\
\hline 9 & Harvesting of & 750 & 1500 & 1500 & 0 & 625 & 500 & 1500 & 911 & 1.26 \\
\hline 10 & $\begin{array}{l}\text { Trashing and } \\
\text { milling of }\end{array}$ & 1000 & 750 & 1500 & 625 & 1750 & 1500 & 3000 & 1446 & 2.00 \\
\hline 11 & Irrigating the farm & 0 & 0 & 2500 & 0 & 0 & 0 & 2500 & 714 & 0.99 \\
\hline 12 & $\begin{array}{l}\text { Transport, } \\
\text { loading and } \\
\text { unloading, and }\end{array}$ & 1000 & 750 & 1500 & 750 & 1000 & 1000 & 1000 & 1000 & 1.38 \\
\hline 13 & $\begin{array}{l}\text { Transport, } \\
\text { loading and } \\
\text { unloading, and }\end{array}$ & 1800 & 3125 & 6375 & 1875 & 3000 & 3000 & 5500 & 3525 & 4.86 \\
\hline \multirow[t]{2}{*}{14} & Uprooting of & 2000 & 2500 & 2500 & 2000 & 2000 & 2500 & 2500 & 2286 & 3.15 \\
\hline & Total expense & 54050 & 76625 & 113625 & 46250 & 60125 & 68250 & 88500 & 72489 & 100 \\
\hline 1 & Income from & 57000 & 60000 & 100000 & 35000 & 50000 & 50000 & 70000 & & \\
\hline \multirow[t]{3}{*}{2} & Income from pigeon & 17500 & 20000 & 40000 & 12500 & 18750 & 31250 & 37500 & & \\
\hline & Total income & 74500 & 80000 & 140000 & 47500 & 68750 & 81250 & 107500 & & \\
\hline & Profit per hectare & 20450 & 3375 & 26375 & 1250 & 8625 & 13000 & 19000 & & \\
\hline
\end{tabular}

\section{Systemic Synthesis of the Agrarian Crisis}

Agrarian system is assumed to comprise six subsystems, namely, indebtedness, land fertility, water table, cattle population, farm size, and human population. Six stock flow diagrams representing the dynamics of these agrarian subsystems are elaborated in appendix 1. Non-linear or linear interrelationships between a numbers of elements govern the dynamics of these subsystems. Various exogenous elements or variables (that cannot be controlled locally) and endogenous variables (that can be controlled locally) caused depletion of the 
agrarian system that has got trapped into a number of self-reinforcing vicious cycles as elaborated below.

Table 3: Total average expense and income for various selected villages for soybean and pigeon pea

\begin{tabular}{|c|c|c|c|c|c|c|c|c|c|c|c|}
\hline $\begin{array}{l}\text { Serial } \\
\text { number }\end{array}$ & Particulars & $\begin{array}{l}\text { Yeulkhed } \\
(\mathrm{Ru}- \\
\text { pees/ha) }\end{array}$ & $\begin{array}{l}\text { Takarkhed } \\
\text { Sambhu } \\
\text { (Big } \\
\text { farmers) } \\
\text { (Ru- } \\
\text { pees/ha) }\end{array}$ & $\begin{array}{l}\text { Takarkhed } \\
\text { Sambhu } \\
\text { (Marginal } \\
\text { farmers) } \\
\text { (Ru- } \\
\text { pees/ha) }\end{array}$ & $\begin{array}{l}\text { Tivsa } \\
\text { (Rain } \\
\text { fed } \\
\text { farm) } \\
\text { (Ru- } \\
\text { pees/ha) }\end{array}$ & $\begin{array}{l}\text { Tivsa } \\
\text { (Irrigated } \\
\text { farm) } \\
(\mathrm{Ru}- \\
\text { pees/ha) }\end{array}$ & $\begin{array}{l}\text { Pathari } \\
(\mathrm{Ru}- \\
\text { pees/ha) }\end{array}$ & $\begin{array}{l}\text { Borisinha } \\
(\mathrm{Ru}- \\
\text { pees/ha) }\end{array}$ & $\begin{array}{l}\text { Shivni } \\
(\mathrm{Ru}- \\
\text { pees/ha) }\end{array}$ & $\begin{array}{l}\text { Average } \\
\text { expense } \\
\text { for each } \\
\text { activity } \\
\text { (Ru- } \\
\text { pees/ha) }\end{array}$ & $\begin{array}{l}\text { Percentage } \\
\text { of total } \\
\text { expense }\end{array}$ \\
\hline 1 & $\begin{array}{l}\text { Ploughing and } \\
\text { cleaning the farm }\end{array}$ & 3500 & 7000 & 7000 & 6250 & 6250 & 3750 & 4500 & 5000 & 5406 & 11.94 \\
\hline 2 & $\begin{array}{l}\text { Sowing pigeon } \\
\text { pea }\end{array}$ & 2625 & 1125 & 3375 & 3000 & 3000 & 375 & 3000 & 750 & 2156 & 4.76 \\
\hline 3 & Sowing soybean & 6500 & 5250 & 9000 & 7250 & 7250 & 8500 & 8250 & 8250 & 7531 & 16.64 \\
\hline 4 & $\begin{array}{l}\text { Fertilizers } \\
\text { application }\end{array}$ & 4250 & 6500 & 6000 & 2625 & 2625 & 3250 & 1500 & 3000 & 3719 & 8.22 \\
\hline 5 & Tilling & 500 & 2000 & 2000 & 1000 & 1000 & 500 & 500 & 500 & 1000 & 2.21 \\
\hline 6 & $\begin{array}{l}\text { Weeding/herbicides } \\
\text { spraying }\end{array}$ & 1750 & 3000 & 1500 & 1000 & 1000 & 1750 & 3000 & 2500 & 1938 & 4.28 \\
\hline 7 & $\begin{array}{l}\text { Insecticides } \\
\text { spraying }\end{array}$ & 4000 & 8625 & 7875 & 8750 & 18750 & 2500 & 1500 & 1250 & 6656 & 14.70 \\
\hline 8 & Tonic spraying & 0 & 2250 & 2250 & 0 & 0 & 0 & 0 & 0 & 563 & 1.24 \\
\hline 9 & $\begin{array}{l}\text { Harvesting } \\
\text { Soybean }\end{array}$ & 3750 & 4000 & 4000 & 5000 & 5000 & 4500 & 3000 & 3750 & 4125 & 9.11 \\
\hline 10 & Irrigating the farm & 0 & 1500 & 0 & 0 & 1250 & 0 & 0 & 1000 & 469 & 1.04 \\
\hline 11 & $\begin{array}{l}\text { Harvesting pigeon } \\
\text { pea }\end{array}$ & 1500 & 3750 & 3750 & 1500 & 2000 & 0 & 3000 & 3000 & 2313 & 5.11 \\
\hline 12 & $\begin{array}{l}\text { Trashing and } \\
\text { milling of pigeon }\end{array}$ & 1250 & 3000 & 3000 & 2000 & 3125 & 750 & 2000 & 2000 & 2141 & 4.73 \\
\hline 13 & Milling of Soybean & 3000 & 2500 & 2500 & 3000 & 4000 & 2500 & 2500 & 2500 & 2813 & 6.21 \\
\hline 14 & $\begin{array}{l}\text { Transport, loading } \\
\text { and unloading, and } \\
\text { commission to the } \\
\text { dealer for pigeon } \\
\text { pea }\end{array}$ & 1000 & 2875 & 2875 & 1000 & 1500 & 750 & 750 & 625 & 1422 & 3.14 \\
\hline 15 & $\begin{array}{l}\text { Transport, loading } \\
\text { and unloading, and } \\
\text { commission to the } \\
\text { dealer for soybean }\end{array}$ & 2250 & 2125 & 2125 & 2250 & 3000 & 1875 & 1875 & 625 & 2016 & 4.45 \\
\hline \multirow[t]{2}{*}{16} & bullock raising & 0 & 8000 & 0 & 0 & 0 & 0 & 0 & 0 & 1000 & 2.21 \\
\hline & Total expense & 35875 & 63500 & 57250 & 44625 & 59750 & 31000 & 35375 & 34750 & 45266 & 100 \\
\hline 1 & $\begin{array}{l}\text { Income from } \\
\text { soybean }\end{array}$ & 42625 & 44000 & 36000 & 31000 & 39000 & 31000 & 37500 & 36425 & & \\
\hline \multirow[t]{3}{*}{2} & $\begin{array}{l}\text { Income from } \\
\text { pigeon pea }\end{array}$ & 20000 & 50000 & 30000 & 25000 & 35000 & 9250 & 18750 & 22500 & & \\
\hline & Total income & 62625 & 94000 & 66000 & 56000 & 74000 & 40250 & 56250 & 58925 & & \\
\hline & $\begin{array}{l}\text { Total profit per } \\
\text { hectare }\end{array}$ & 26750 & 30500 & 8750 & 11375 & 14250 & 9250 & 20875 & 24175 & & \\
\hline
\end{tabular}




\subsection{Indebtedness Subsystem}

Qualitative model represented by a Stock flow diagram of the indebtedness subsystem (see figure 12) is depicted in appendix 1. Exogenous variables and endogenous variables of the subsystem causing a number of vicious loops are elaborated below.

\subsubsection{Exogenous Variables and Endogenous Variables in Indebtedness Subsystem}

Exogenous variables include increasing inequality between agriculture and non-agricultural sectors, poor agricultural extension services, declining regulated credit structures, deterioration of public education and public health services, inflation, inappropriate support prices, global warming, and thinning of forest cover.

These variables led to the adoption of less appropriate Green Revolution technologies to the arid and semiarid areas. It made agricultural practices synthetic input intensive, investment intensive (investment on seeds, fertilizers, pesticides, irrigation, plowing, and labor), and vulnerable to the climatic conditions. These causes combined with the effects of Global warming and thinning of forests further exacerbated the crisis by deteriorating soil and water resources. Reduction in the state subsidies in fertilizers, pesticides and seeds along with inadequate support prices determined by the state and international tread dynamics reduced the profits drastically. Expensive and ineffective public education and healthcare services further increased the economic burden of the farmers. Inadequate state support in credit alternatives worsened the problems of the farmers. These factors pushed the farmers into vicious cycles of indebtedness. These exogenous factors are not in control of unorganized farmers. State, market, and volunteer agencies must intervene to mitigate the effects of these exogenous factors.

Endogenous factors such as inflated wedding practices (mainly due to the tradition of dowry) and liquor consumption, have contributed to increase the level of indebtedness. Mono cropping increases pests (by providing sufficient and uninterrupted food to certain pests) and reduces soil fertility as this practice persistently extracts only a particular set of nutrients from the soil. Mono cropping also increases dependency on market for certain food items such as some pulses and vegetables that used to be derived from the farm.

\subsubsection{Loops in Indebtedness Subsystem}

This subsystem involves 39 self-reinforcing closed loops (or vicious cycles) of different elements that are increasing the rate of indebtedness with time. These are depicted in figures 7, 8, 9, and 10. Two separate loops emerging from a diagram are depicted in figure 7 . The remaining loops listed in the present section and the following sections are aggregated in a few figures due to space constraints of the article. These vicious cycles are elaborated below.

Once a farmer becomes a defaulter to a nationalized bank due to the incapability of repayment, he/she cannot get an additional loan from the bank. This reduces the regulated credit alternatives and the farmer is forced to get the required loan from unregulated sources at inflated interest rates (see figure 7). Further crop failure worsens the situation by increasing the rate of indebtedness. Indebtedness increases the delays in procuring the loans that further 
delays the cultivation practices and reduces the probability of getting a normal yield followed by increased indebtedness. Indebtedness increases tendency of farmers to migrate and to aspire for non-agricultural livelihood alternatives (Sainath, 2013) for his/her children (see figure 8). Migration reduces number of people in household and thus the capacity of a household to raise cattle. A farmer's aspiration to educate his/her children increases the expense on education. Increased indebtedness also increases addiction and thereby the health problems. This increases the overall living expense. The increased expense may force a farmer to sell the cattle. Secondly, indebtedness itself also forces a farmer to sell his/her cattle (see figures 8 and 9). Reduction in the cattle owned by the farmers increases the expense on irrigation, inorganic fertilizers, and plowing thereby increasing the investment on agriculture and further increasing the indebtedness (see figures 8 and 9). Reduction in organic manure reduces moisture holding capacity of soil and thus increases the demand for irrigation (Vengadaramana \& Jashothan, 2012; Tadesse, Dechassa, Bayu, \& Gebeyehu, 2013) (this is also increased by mono-cropping) and thus the expenditure on irrigation and the investment on agriculture (see figure 26). Reduction in the application of organic manure reduces biological mechanism to control disease causing bacteria (Bonanomi, Antignani, Capodilupo, \& Scala, 2010; Bailey \& Lazarovits, 2003). It also increases nutrient imbalance and vulnerability of plants to insect attacks (Altieri \& Nicholls, 2003). This increases expenditure on herbicides and insecticides and the investment on agriculture.

Extensive usage of inorganic fertilizers contaminate ground water and increases the health related problems (Rao \& Puttanna, 2000; Deshmukh, 2012; Majumdar \& Gupta, 2000; Datta, 2013; Yu, Jun-biao, \& Jiang, 2009). This increases the overall living expenditure and indebtedness (see figure 27). Reduction in the cattle population also reduces the consumption of milk and reduces the nutrition level of the food that may increase the health related problems (see figure 9). Increased health problems further increases the overall living expense. Increase in the overall living expense due to the increased expense on education, health, and addiction further increases the indebtedness (see figure 8). Tendency of the farmers to seek livelihood alternatives in non-agricultural sector increases migration to urban areas and reduces labor availability in the rural areas thereby increasing labor cost and thus investment in agriculture (see figure 10). This also reduces the number of people in a household for agricultural labor and thus increases the investment in agriculture. 

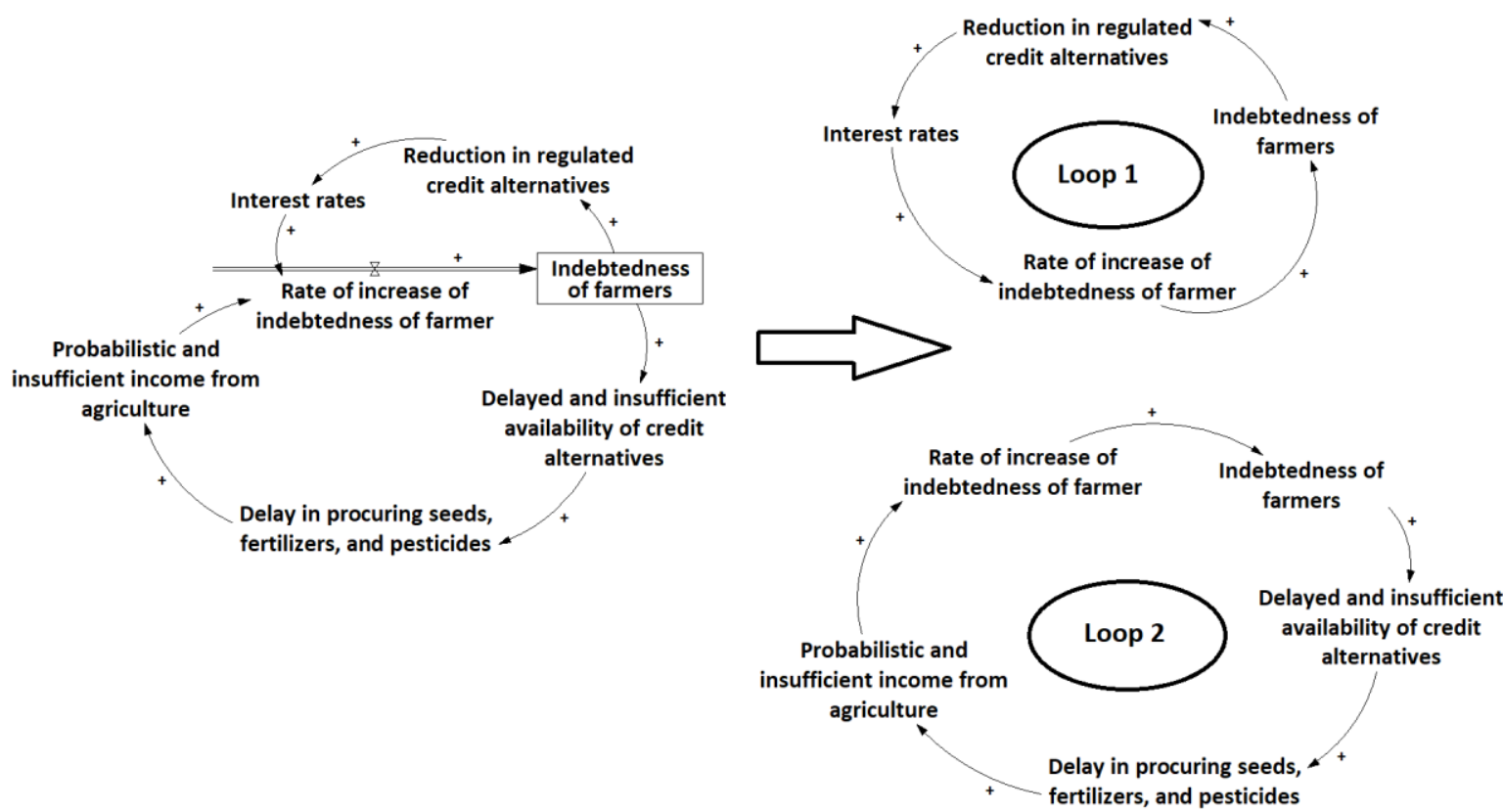

Figure 7: Closed Loops in indebtedness subsystem: a total of 2 reinforcing loops

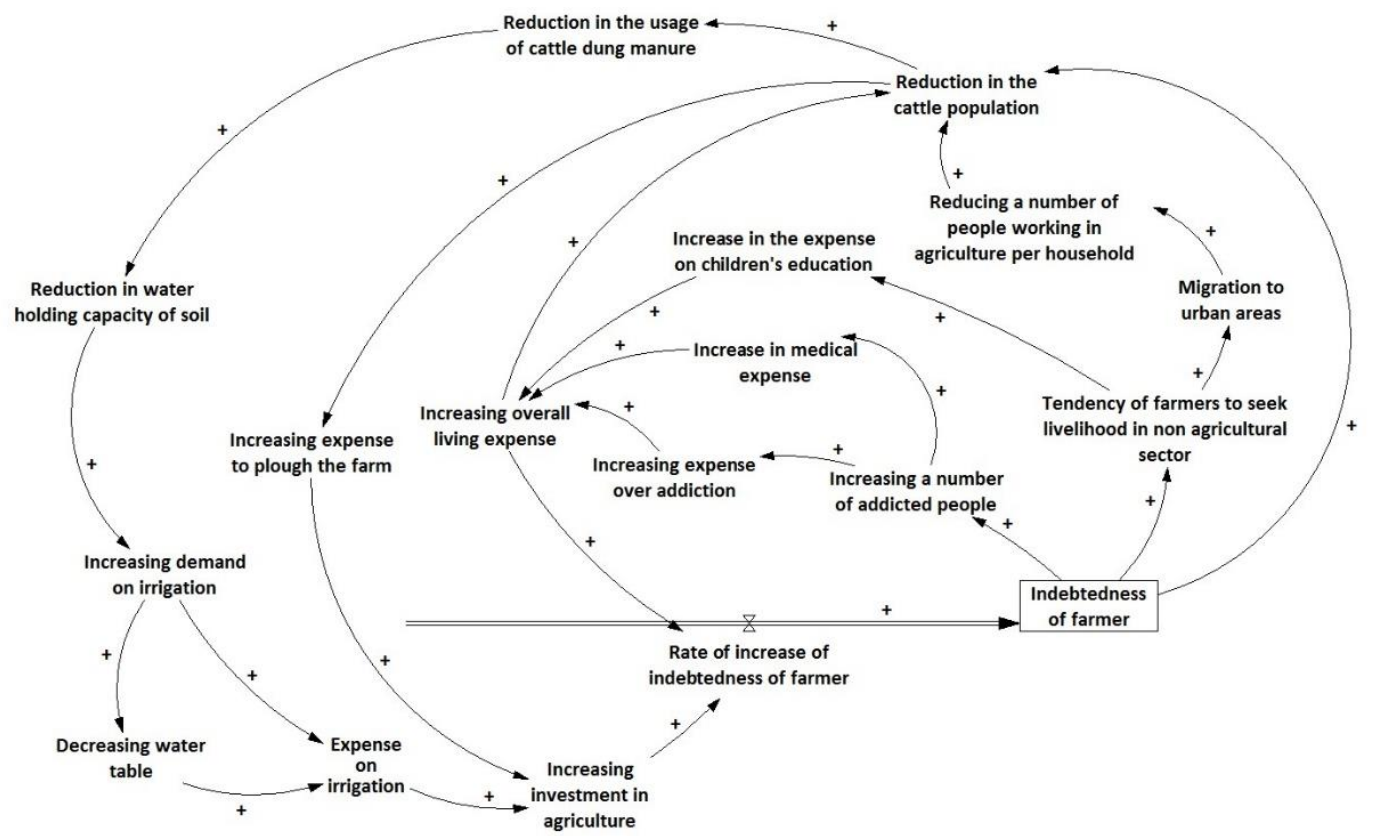

Figure 8: Closed Loops in indebtedness subsystem: a total of 18 reinforcing loops

Increase in the usage of pesticides kills the beneficial insects and birds. This increases the population of certain pests due to the reduction in the population of their natural predators. 


\section{Macrothink}

Journal of Agricultural Studies

ISSN 2166-0379

2018, Vol. 6, No. 1

This process further increases the tendency of using pesticides (Shetty, 2004; Huang, Pray, \& Rozelle, 2002) (see figure 10).

\subsection{Land Fertility}

Qualitative model represented by a Stock flow diagram of the land fertility subsystem is given in appendix 13. Exogenous variables and endogenous variables of the subsystem causing a number of vicious loops are elaborated below.

\subsubsection{Exogenous and Endogenous Variables in Land Fertility Subsystem}

In this subsystem, exogenous variables are increasing inequality, poor agricultural extension services, and reduction in the forest cover. These factors are forcing the farmers to adopt less appropriate Green Revolution technologies that deteriorate the land fertility. Increased usage of insecticides, fungicides, and herbicides incurs detrimental effects on soil biota and the activities of microorganisms that are beneficial for the plant growth (supplying plant nutrients and protection from various pathogens) (Channabasava, Lakshman, \& Jorquera, 2015; Milosevic \& Govedarica, 2002; Zabaloy, Zanini, Bianchinotti, Gomez, M. A., \& Garland, 2011; Clapperton \& Regen, 2012). Reduction in the forest cover increases soil erosion, reduces green manure, and thereby reduces land fertility. Endogenous variables are irrigation and reduction in the usage of cattle dung manure. Excessive irrigation increases salinity of land in arid and semi-arid areas and reduces land fertility (Shrivastava \& Kumar, 2015).

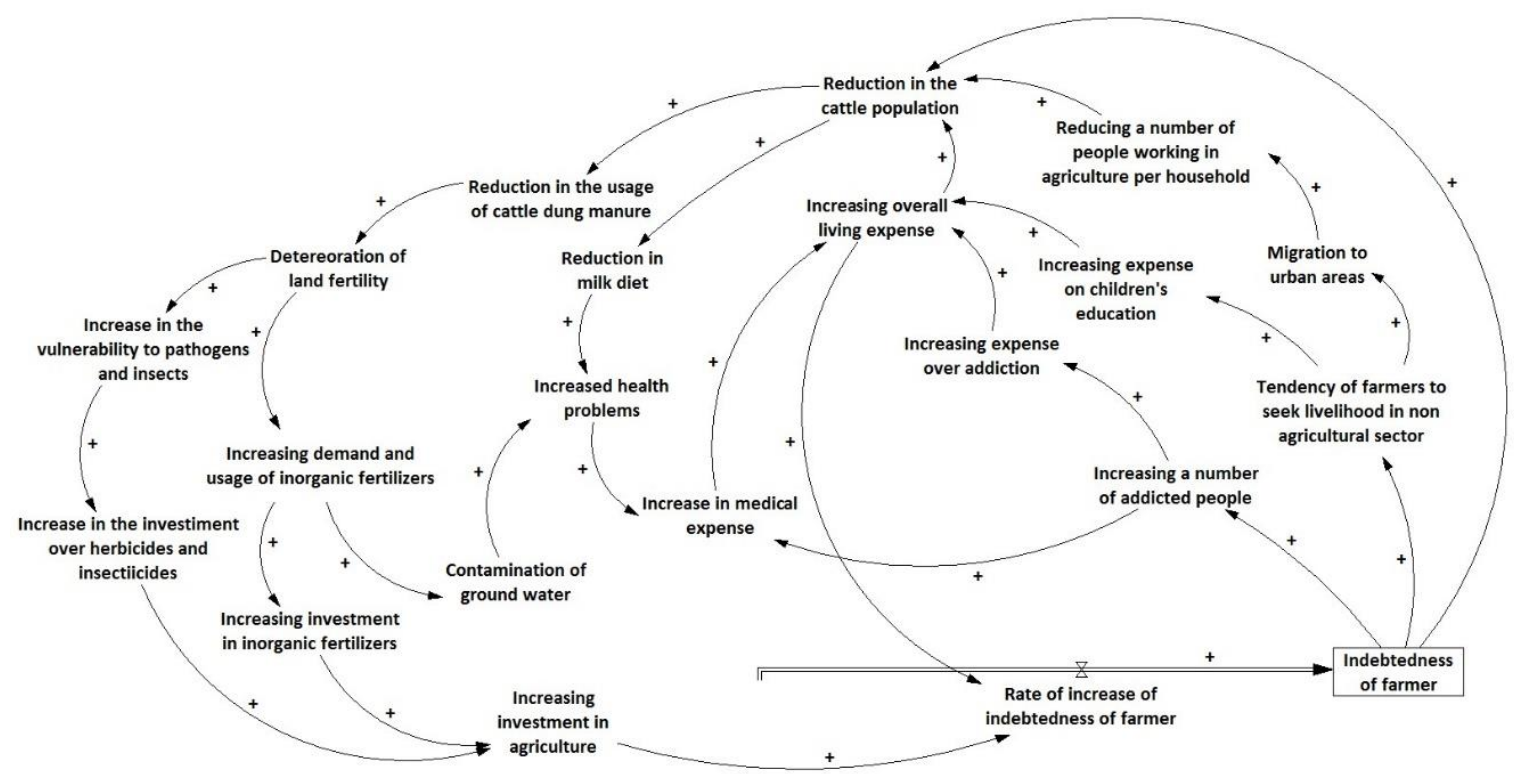

Figure 9: Closed Loops in indebtedness subsystem: a total of 16 reinforcing additional loops 


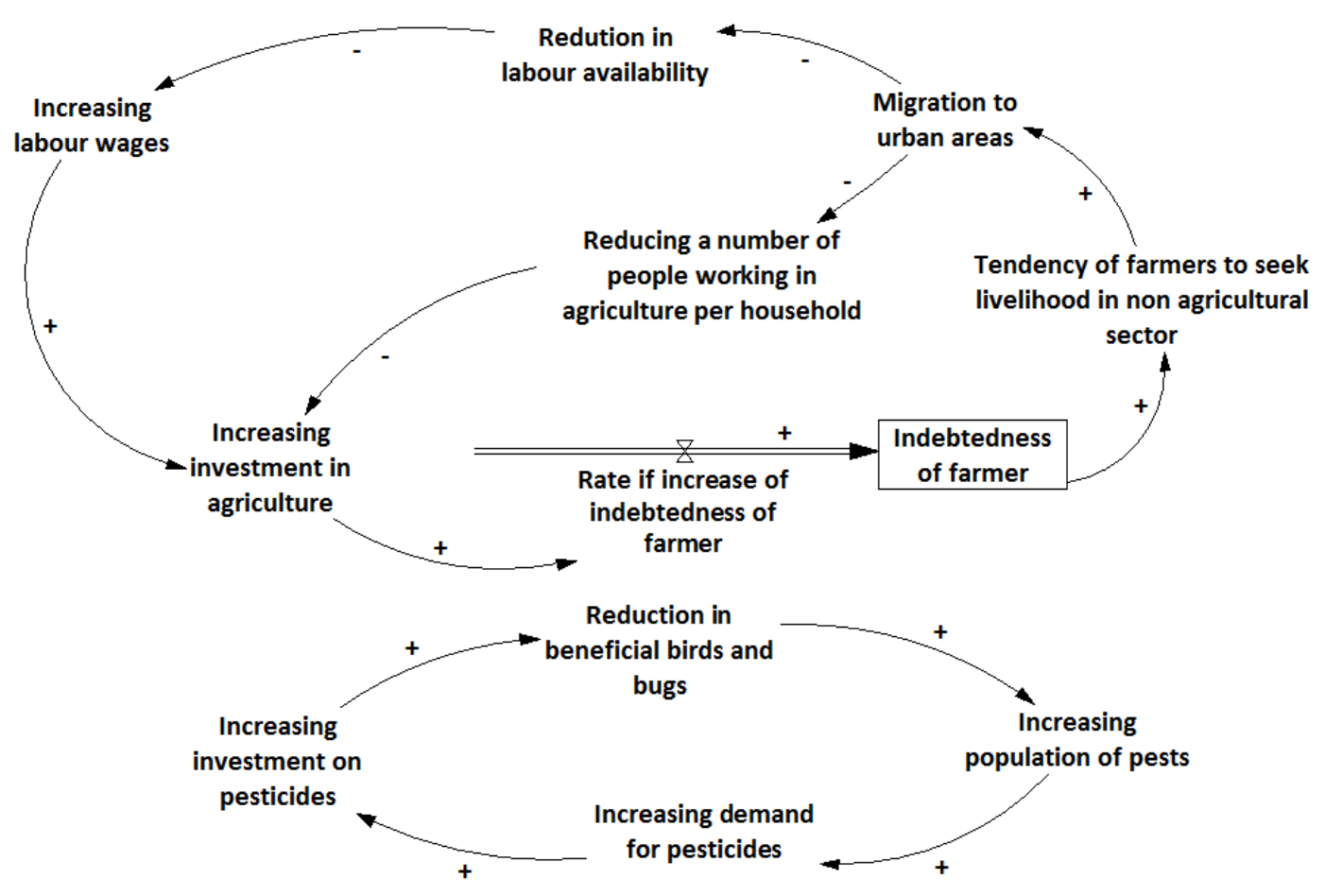

Figure 10: Closed Loops in indebtedness subsystem: a total of 3 reinforcing loops

\subsubsection{Loops in Land Fertility Subsystem}

It can be seen that there are two closed loops of the deterioration of land fertility. Increased usage of inorganic fertilizers increases acidity, affect the activity of microbes, reduce earth worms, and add heavy metals to the soil (Suzuki, 2003; Setboonsarng, 2006; Ashiya \& Rathore, 2014; Savci, 2012). Therefore it reduces land fertility. Increased use of easily available inorganic fertilizers reduces the tendency of farmers to use cattle dung manure and green leaf manure, which demand more human work hours for its procurement. Reduction in the usage of the manures in the soil reduces humus, organic carbon, and microorganisms in the soil. It affects physical, biological, and chemical properties of the soil. It reduces soil micro and macro biota, available N, P, K, S and other essential nutrients, enzyme activity, soil porosity, and aeration in soil (Parnes, 2013; Ramesh, Panwar, Sing, \& Ramana, 2008). It increases soil compaction and affects growth of roots and microbes (Hoorman, de Moraes, \& Reeder, 2009). It also increases the vulnerability of plants to the attacks of disease causing soil borne pathogens and insects (refer section 4.1.2.). Thereby, it reduces soil fertility. Reduction in soil fertility reduces crop yield. It compels the farmers to increase the usage of inorganic fertilizers.

\subsection{Water Table}

Exogenous and endogenous variables for the water table subsystem are the same as the previous subsystem (Land fertility) as shown in figure 14. (Appendix 1). After spreading of less 
appropriate Green Revolution technologies to arid and semi-arid areas, ground water has been drained disproportionately to its rate of recharge (Shiferawa, Reddyb, \& Wanic, 2008). Excessive extraction of ground water for agriculture (that is being disproportionately renewed) has depleted the source (Rodell, Velicogna, \& Famiglietti, 2009; Tiwari, Wahr, \& Swenson, 2009; Aeschbach-hertig \& Gleeson, 2012). Climate change is supposed to further exacerbating the depletion (Shah, 2009; Ferguson \& Gleeson, 2012). The water table has been therefore depleting every year and it has increased the cost of irrigation. There is a threat that the water table would further keep on depleting till it becomes unaffordable for a marginal/medium farmer to extract. There is no loop in the water table subsystem.

\section{4 Cattle Population}

A number of reasons for the rate of reduction of cattle population are already discussed while elaborating the indebtedness subsystem. Comprehensive dynamic linkages of the cattle population are depicted in figure 15 (see appendix 1).

\subsubsection{Exogenous Variables in Cattle Population Subsystem}

Exogenous variables responsible for the rate of reduction of the cattle population are inflation, rising inequality, and poor agricultural extension services. Whereas, endogenous variables are, inflated wedding practices and human population.

\subsubsection{Loops in Cattle Population Subsystem}

Other than a number of loops discussed in the indebtedness subsystem, there are four reinforcing closed loops responsible for the present trend as shown in figure 11. As discussed earlier, the reduction in the cattle population reduces usage of cattle dung manure in the farm. This reduces land fertility (as discussed in section 4.2). It increases the usage of inorganic fertilizers (see figure 3 (e)). It increases the problem of contamination of fodder and water by toxic elements and increases the health problems of the cattle and therefore increases the cost of raising cattle (Katole, Kumar, \& Patil, 2013). This further reduces the cattle population.

Reduction in the cattle population has reduced the cultivation of sorghum (that is mainly cultivated for fodder). Reduction in the cultivated area of sorghum and reduction in the forest cover reduced the availability of fodder for wild animals. This has increased the attacks of wild animals per acre of the cultivated area. This has further reduced the cultivation of sorghum and thus the fodder availability and the cattle population. 


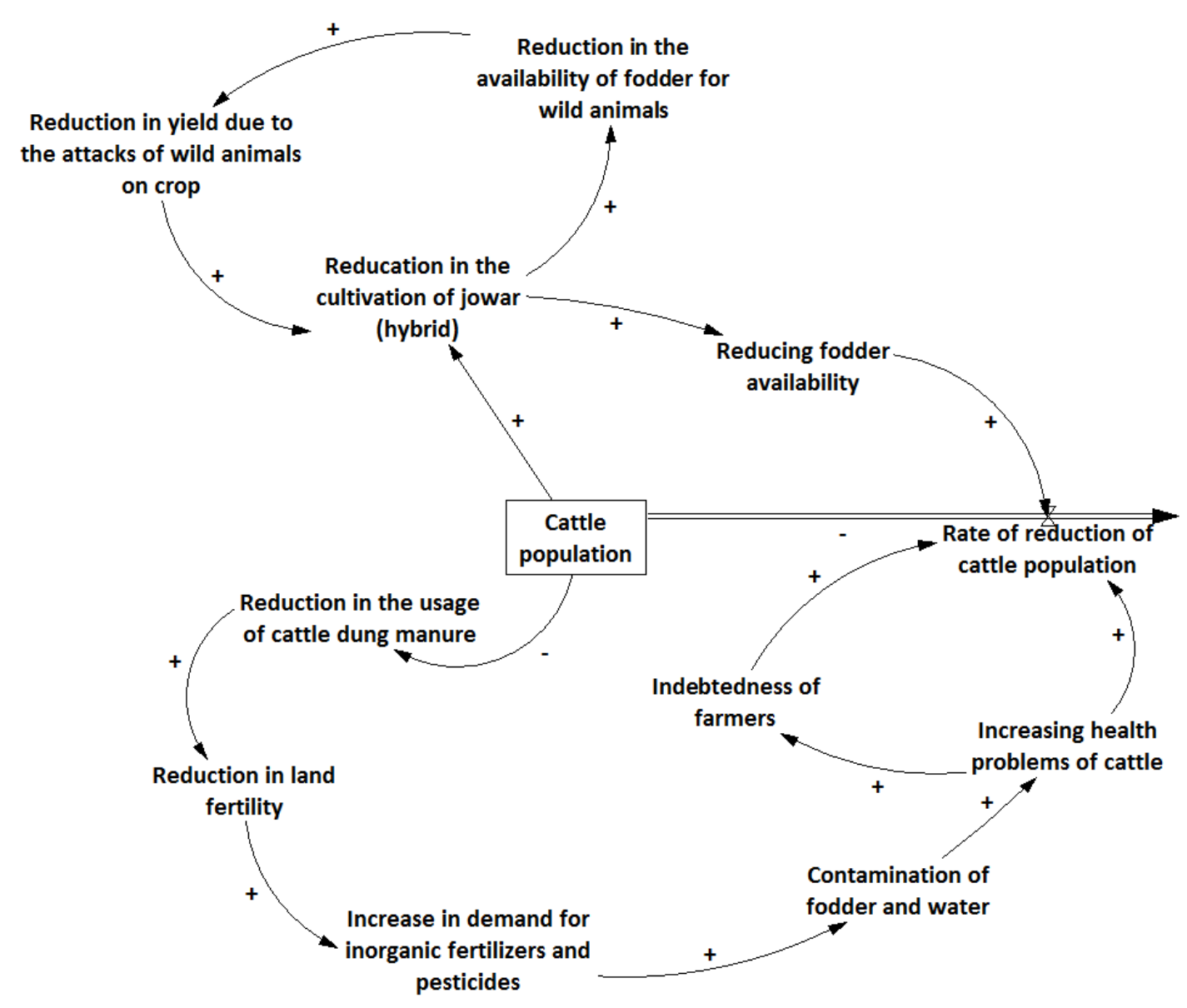

Figure 11: A total of 4 reinforcing loops in cattle population subsystem

\subsection{Farm Size Per Household}

The cultivable farm size per household has reduced mainly due to the increase in the human population and the division of families (see figure 16 in appendix 1). Migration to the urban areas has reduced the availability of the human work hours for agricultural activities. It has increased the fallow farmlands and reduced the cultivable farm size per household. A self-balancing closed loop that incurs the conversion of hay fields in the cultivable lands has increased the farm size slightly. However, this trend imbalances agricultural ecology by reducing the cattle bearing capacity and hence the cattle population as discussed in the previous subsections. Cultivable land also increases due to the building of surface water structures like dams and farm ponds. Availability of the irrigation sources multiplies the total number of crops cultivated per year and brings fallow land under cultivation. In this subsystem, exogenous variables are watershed programs and the availability of non-farm livelihood alternatives in urban areas. An endogenous variable is human population. 


\subsection{Human Population}

Human population has been increasing over the last six decades. Mortality rates have reduced along with the increase in the health services (this has increased the life expectancy). Birth rate did not reduce in proportion with the reduction in the mortality rates leading to the increase in the human population. However, the growth rate of human population has reduced due to the increase in literacy (especially among women) and marriage age (endogenous variables) and various state level population control programs (exogenous variable). Recently, the escalation of the living cost (inflation, an exogenous variable) has also reduced the birth rates in the agrarian community (see figure 17 in appendix 1). This subsystem comprises a self-balancing loop. Increase in the human population has reduced the farm size and so the income from farming. Increased inflation and reduction in the income has compelled the farmers to reduce the birth rate.

\section{Discussion and Conclusion}

Mono-cropping, inorganic fertilizers, hybrid and modified seeds procured from the centralized market, synthetic pesticides, and irrigation technologies showed initial increase in the yield and income per hectare of the land in arid and semi-arid regions. However, it replaced most of the traditional farming practices and affected local agro ecology for more than two decades. Trends comprising reducing farm size, reducing water table, increasing living expense, increasing the expense of wedding, increasing addiction, increasing dearth of agricultural laborers per family, and increasing indebtedness have exacerbated the crisis. Various exogenous factors and endogenous factors contributed in weakening of the agrarian system. As a result, the agrarian system, including agro ecological system, agricultural economics, land holding, and social system has deteriorated and has been trapped into forty five self-reinforcing vicious loops. Out of these, thirty five loops are associated with cattle. It reveals the importance of cattle raising for the sustainability of the agrarian system.

Average investment in the cultivation of cotton is much higher than the investment for the cultivation of soybean (please refer tables 2 and 3). On the other hand, net income from the cultivation of cotton is found to be less than soybean for most of the villages. Therefore the percentage of indebted farmers is lesser for Takarkhed Sambhu village where cotton is not cultivated. The investment for the cultivation of cotton is at least $30 \%$ higher for the irrigated farmlands. This is one of the reasons for the fact that instead of having dissimilarity in the sources for irrigation, the percentage of indebtedness is relatively similar for the selected villages (other than Takarkhed Sambhu). This observation also reflects that the provision of water for irrigation is not the only remedy for the present agrarian crisis. The overall agrarian system is depleted and thus it is required to bring a system of interventions that would build a healthy agrarian system to address the crisis. The analysis presented in tables 2 and 3 also reflects that the cultivation of rain fed cotton is not a viable alternative.

The present study concludes the following dimensions of the Agrarian crisis. (i) Most of the facets of the agricultural ecology have depleted over the past two decades. Agrarian system has become trapped in forty five self-reinforcing vicious loops. As a result, the cultivation practices have been subjected to a trend of increasing inputs; (ii) Agriculture has become 
investment intensive and dependent on the centralized market, mainly for seeds, fertilizers and pesticides (around $44 \%$ of the total investment for the cultivation of cotton) and agricultural laborers (around $47 \%$ of the total investment for the cultivation of cotton). There is an increased dependency on money and thereby formal and informal credit institutions to cater the investment on cultivation; (iii) Crops have become vulnerable to the vagaries of climatic conditions, pest attacks, various plant diseases, low soil fertility, and water stresses. Farmers face frequent problems of crop failures due to the depleting agro ecology and lack of capacity of the hybrid and genetically modified crops to bear the environmental stresses. There is an increased dependency on the centralized market and its local outlets for knowledge to find remedies for various diseases and pest attacks; (iv) Agriculture has also been subjected to a risk of disproportionate market prices of the agricultural produce that does not take into account the input expense due to the lack of regulation majors and its effective implementation; and (v) Living expense has also increased due to the increase in the expense of children's education, health care, wedding, and increased addictions. Due to the above factors, majority farmers are pushed into a vortex of indebtedness and some of them committed suicide to get rid of the trap.

Farmers seek suggestions from field officers of various agricultural input companies, agricultural input (seed, fertilizers, and pesticides) shops, and their fellow farmers due to the less effective agricultural extension systems, lack of the farmers' capacity to deal with the depleting agro ecology, and the vulnerability of the crops. As none of the consulted entities are experts in understanding the systemic and context specific agrarian systems, the farmer and the farming systems are drawn into the vortex of non-sustainability.

Responsible market, state, volunteer organizations, and farmers have to intervene to address the problems created by the exogenous variables, vicious loops, and endogenous variables. It is important to bring radical changes in the present agricultural practices. The agricultural practices shall be less dependent on the centralized market and shall be responsible for ensuring healthier agro ecological systems and viable agro-economic and agro-social systems.

\section{Acknowledgement}

The authors are grateful to a volunteer organization, Deendayal Bahu-uddeshiya Prasarak Mandal, Yavatmal for their valuable participation for carrying out participatory exercises in the four selected villages in Yavatmal district. The authors are also grateful to more than 120 farmers from the six selected villages who have participated in the participatory exercises.

\section{References}

Ahmad, M. F., \& Haseen, S. (2012). The performance of India's food grains production: A pre and post reform assessment. International Journal of Scientific and Research Publications, 2(3), 1-15.

Aeschbach-hertig, W., \& Gleeson, T. (2012). Regional strategies for the accelerating global problem of groundwater depletion. Nature Geoscience, 5(12), 853-861.

https://dx.doi.org/10.1038/ngeo1617 
Altieri, M. A. (2009). Agroecology, Small Farms, and Food Sovereignty. Monthly Review, 61 (3), 102-113. https://dx.doi.org/10.14452/MR-061-03-2009-07_8

Altieri, M. A., \& Nicholls, C. I. (2003). Soil fertility management and insect pests: harmonizing soil and plant health in agroecosystems. Soil \& Tillage Research, 72, 203-211. https://dx.doi.org/10.1016/S0167-1987(03)00089-8

Ashiya, N. R. P., \& Rathore, D. S. (2014). Comparative study of the effect of chemical fertilizers and organic fertilizers on eisenia. International Journal of Innovative Research in Science, Engineering and Technology, 3(5), 12991-12998.

Azam, M. (2012). The impact of Indian job guarantee scheme on labor market outcomes: Evidence from a natural experiment. Technical Report IZA Discussion Paper No. 6548, Institute for the study of labor.

Bailey, K., \& Lazarovits, G. (2003). Suppressing soil-borne diseases with residue management and organic amendments. Soil and Tillage Research, 72(2), 169-180.

https://dx.doi.org/10.1016/S0167-1987(03)00086-2

Basu, D., Das, D., \& Mishra, K. (2016). Farmer Suicides in India. Economic \& Political Weekly, 51(21), 61-65.

Berg, E., Bhattacharyya, S., Durgam, R., \& Ramachandra, M. (2012). Can rural public works affect agricultural wages: Evidence from India. Technical Report CSAE Working Paper WPS/2012- 05, Centre for the Study of African Economies.

Berg, H. (2001). Pesticide use in rice and rice-fish farms in the Mekong delta, Vietnam. Crop Protection, 20(10), 897-905. https://dx.doi.org/10.1016/S0261-2194(01)00039-4

Bhalla, G. S., \& Singh, G., (2009). Economic Liberalisation and Indian Agriculture: A State-wise Analysis. Economic \& Political Weekly, 44(52), 34-44.

Boatman, N. D., Brickle, N. W., Hart, J. D., Milsom, T. P., Morris, A. J., Murray, A. W. A., Murray, K. A., \& Robertson, P. A. (2004). Evidence for the indirect effects of pesticides on farmland birds. IBIS, 146(2), 131-143. https://dx.doi.org/10.1111/j.1474-919X.2004.00347.x

Bonanomi, G., Antignani, V., Capodilupo, M., \& Scala, F. (2010). Identifying the characteristics of organic soil amendments that suppress soil borne plant diseases. Soil Biology \& Biochemistry, 42, 136-144. https://dx.doi.org/10.1016/j.soilbio.2009.10.012

Capra, F. (1996). The Web of Life. Great Britain: Harper Collins Publishers.

Challa, J., Joshi, P. K., \& Tamboli P. (2011). Revitalizing Higher Agricultural Education in India. Economic \& Political Weekly, 46 (26, 27), 326-329.

Chambers, R. (2008). Revolutions in Development Inquiry. London: Earthscan.

Chand, R. (2006). India's agricultural challenges and their implications for growth and equity. Paper presented at Silver Jubilee Seminar on Perspectives on equitable Development: International Experience and What Can India Learn? Centre for Economic and Social Studies, 


\section{MInstitute ${ }_{\text {Mnk }}^{\text {Macrothin }}$}

Hydrabad.

Chandramauli, C. (2011). Census of India 2011, Rural urban distribution of population. Technical report, Ministry of Home Affairs, New Delhi.

Channabasava, Lakshman, H., \& Jorquera, M. (2015). Effect of fungicides on association of arbuscular mycorrhiza fungus rhizophagus fasciculatus and growth of proso millet. Journal of Soil Science and Plant Nutrition, 15(1), 35-45.

https://dx.doi.org/10.4067/S0718-95162015005000004

Chauhan, S., \& Aeri, D. B. T. (2013). Prevalence of cardiovascular disease in India and it is economic impact- a review. International Journal of Scientific and Research Publications, $3(10), 5$.

Clapperton, J., \& Regen, M. (2012). Pesticide effects on soil biology. [Online] available: https://gardendrum.com/wp-content/uploads/2012/11/PesticideEffectsOnSoilBiology.pdf (January 8, 2018).

Coyle, G. (2000). Qualitative and quantitative modelling in system dynamics: some research questions. System Dynamics Review 16 (3), 225-244.

https://dx.doi.org/10.1002/1099-1727(200023)16:3<225::AID-SDR195>3.0.CO;2-D

Datta, P. S. (2013). Groundwater vulnerability to changes in land use and society in India. In Understanding Freshwater Quality Problems in a Changing World, volume 361. Sweden: IAHS Publication.

Deshmukh, K. K. (2012). Ground water quality evaluation with special reference to nitrate pollution in the Sangamner area, Ahmednagar district, Maharashtra, India. WIT Transactions on Ecology and The Environment, 164, 79-88. https://dx.doi.org/10.2495/WP120071

Dhas, R. A. C. (2009). Agricultural crisis in India: The root cause and consequences. MPRA Paper No. 18930. [Online] Available:

https://mpra.ub.uni-muenchen.de/18930/1/MPRA_paper_18930.pdf (August 11, 2017).

European Commission, (2009). New Challenges for Agricultural Research: Climate Change, Food Security, Rural Development, Agricultural Knowledge Systems, European Communities, Luxembourg. http://dx.doi.org/10.2777/6185

Ferguson, G., \& Gleeson, T. (2012). Vulnerability of coastal aquifers to groundwater use and climate change. Nature Climate Change, 2(5), 342-345.

https://dx.doi.org/10.1038/nclimate1413

Forrester, J. W. (1971). World Dynamics. New York: Wright-Allen Press.

Government of India (2005). Economic survey 2004-2005. Technical report, Ministry of Finance, New Delhi.

Government of India (2010). Ground water scenario of India 2009-2010. Technical report, Central Ground water Board, Ministry of Water resources, [Online] available:

http://www.cgwb.gov.in/ (January 18, 2017) 


\section{$\triangle$ Macrothink}

Journal of Agricultural Studies

ISSN 2166-0379

2018, Vol. 6, No. 1

Gregory, R. D., David, Noble, G., \& Custance, J. (2004). The state of play of farmland birds: population trends and conservation status of lowland farmland birds in the United Kingdom. IBIS, 146(2), 1-13. https://dx.doi.org/10.1111/j.1474-919X.2004.00358.x

Henry, M., Beguin, M., Requier, F., Rollin, O., Odoux, J.-F., Aupinel, P., Aptel, J., Tchamitchian, S., \& Decourtye, A. (2012). A common pesticide decreases foraging success and survival in honey bees. Science, 336(6079), 348-350.

https://dx.doi.org/10.1126/science.1215039

Honkalaskar V. H., Sohoni, M., \& Bhandarkar, U. V. (2017). Selection of development agenda with the community by the generation of a shared understanding. The Journal of Rural and Community Development.12 (1), 76-98

Hoorman, J. J., de Moraes Sa, J. C., \& Reeder, R. (2009). The biology of soil compaction. Technical Report AEX-543-09, The Ohio State University.

Huang, J., Pray, C., \& Rozelle, S. (2002). Enhancing the crops to feed the poor. Nature, 418, 678- 684. https://dx.doi.org/10.1038/nature01015

Imbert, C. and Pappa, J. (2013). Labor market effects of social programs: Evidence from India's employment guarantee. Technical Report CSAE Working Paper WPS/2013-03, Centre for the Study of African Economies.

Kalamkar, S. S. (2013). Agrarian Crisis in India: The way out, chapter Agrarian Crisis and food security in India, pages 235-282. New Delhi: Academic foundation.

Karmarkar, N. (2007). Agrarian Crisis in India: An overview, chapter Agrarian distress: The Indian story, pages 39-52., Hydrabad, India: The ICFAI University Press.

Katole, S. B., Kumar, P., \& Patil, R. D. (2013). Environmental pollutants and livestock health: a review. Veterinary Research International, 1(1), 1-13.

Kohler, H.-R., \& Triebskorn, R. (2013). Wildlife ecotoxicology of pesticides: Can we track effects to the population level and beyond? Science, 341(6147), 759-765.

https://dx.doi.org/10.1126/science.1237591

Krupke, C., Hunt, G., Eitzer, B., Andino, G., \& Given, K. (2012). Multiple routes of pesticide exposure for honey bees living near agricultural fields. PLoS ONE, 7(1), 1-8. https://dx.doi.org/10.1371/journal.pone.0029268

Majumdar, D., \& Gupta, N. (2000). Nitrate pollution of groundwater and associated human health disorders. Indian Journal of Environmental Health, 42(1), 28-39.

Milosevic, N. A., \& Govedarica, M. M. (2002). Effect of herbicides on microbiological properties of soil. Matica Srpska Journal of Natural Sciences, 102, 5-21.

https://dx.doi.org/10.2298/ZMSPN0201005M

Ministry of Agriculture, Government of India (2009). [Online] Available: www.indiastat.com (September 15, 2016). 
Mishra, S. (2006). Suicide of farmers in Maharashtra. Submitted to the Government of Maharashtra. Mumbai: Indira Gandhi Institute of Development Research.

Mishra, S. (2007). Agrarian scenario in post-reform India: A story of distress, despair and death.Technical report, Mumbai: Indira Gandhi Institute of Development Research.

Mukherjee, S. (2009). Examining farmer suicides in India: A study of literature, MPRA paper no. 35675. [Online] Available: https://mpra.ub.uni-muenchen.de/35675/ (August 8, 2017)

Murielle (2009). Monocrop farming: Green revolution or environmental blunder of historic proportions? [Online] Available:

http://www.greenfudge.org/2009/09/24/monocrop-farming-green-revolution-or-environmenta l-blunder-of-historic-proportions/ (December 13, 2016)

Oyo, B., Williams, D., \& Barendsen, E. (2009). Integrating Action Research and System Dynamics: Towards a Generic Process Design for Participative Modeling. Paper presented at the 2009 Hawaii International Conference on System Sciences, ISBN 978-0- 7695-3450-3, ISSN 1530-1605. IEEE Computer Society

Parnes, R. (2013). Soil fertility: A guide to organic and inorganic soil amendments. [Online] Available: http://soilandhealth.org/ September 4, 2016).

Prasanna, P. L. (2013). Agrarian Crisis in India: The way out, chapter Changes in land holding structure in Indian agriculture, pages 48-64, New Delhi: Academic foundation.

Pruyt, E., (2013). Small System Dynamics Models for Big Issues: Triple Jump towards Real-World Complexity. Delft: TU Delft Library. 324p.

Raghavan, M. (2008). Changing Pattern of Input Use and Cost of Cultivation. Economic \& Political Wekly, 43(26, 27), 123-129.

Rajeev, M., Vani, B. P., \& Bhattacharjee, M. (2011). Nature and dimensions of farmers' indebtedness in India and Karnataka. Technical report, Working paper 267, The Institute of Social and Economic Change, Bangalore.

Ramesh, P., Panwar, N. R., Sing, A. B., \& Ramana, S. (2008). Effect of organic manures on productivity, soil fertility, and economics of soybean (glycine max) - drum wheat (triticum durum) cropping system under organic farming in vertisols. Indian Journal of Agricultural Sciences, 78(12), 1033-1037.

Rao, E. V. S. P., \& Puttanna, K. (2000). Nitrates, agriculture and environment. Current Science, 79(9), 1163-1168.

Reddy, D. N., \& Mishra, S. (2009). Agrarian Crisis in India. New Delhi: Oxford University Press.

Rodell, M., Velicogna, I., \& Famiglietti, J. S. (2009). Satellite-based estimates of groundwater depletion in India. Nature, 60(7258), 999-1002.

https://dx.doi.org/10.1038/nature08238 
Roy, T. (2006). Roots of agrarian crisis in interwar India retrieving a narrative. Economic and Political Weekly, special articles, 5389-5400.

Saeed, K. (1998). Defining a problem or constructing a reference mode. [Online] Available: https://www.systemdynamics.org/assets/conferences/1998/PROCEED/00016.PDF (February 13, 2018).

Sainath, P. (2007). The farm crisis: why have over one lakh farmers killed themselves in the past decade? Speakers Lecture Series: Parliament House. [Online] Available:

https://psainath.org/the-farm-crisis-why-have-over-one-lakh-farmers-killed-themselves-in-the -past-decade/ (February 13, 2018)

Sainath, P. (2013). Over 2,000 fewer farmers every day. [Online] Available: https://psainath.org/over-2000-fewer-farmers-every-day/ (August 17, 2017).

Sainath, P. (2014). Maharashtra crosses 60,000 farm suicides. [Online] Available: https://psainath.org/farm-suicide-trends-in-2012-remain-dismal/ (August 17, 2017).

Sainath, P. (2015). The slaughter of suicide data. [Online] Available: https://psainath.org/the-slaughter-of-suicide-data/, (August 17, 2017).

Savci, S. (2012). An agricultural pollutant: Chemical fertilizer. International Journal of Environ- mental Science and Development, 3(1), 77-80.

https://dx.doi.org/10.7763/IJESD.2012.V3.191

Sen, A., \& Bhatia, M. S. (2004). State of Indian farmer: A millennium study - Cost of cultivation and farm income, vol. 14. Technical report, New Delhi: Academic Foundation.

Setboonsarng, S. (2006). Organic agriculture, poverty reduction, and the millennium development goals. Technical Report Discussion paper number 54, Asian Development Bank Institute.

Shah, T. (2009). Climate change and groundwater: India's opportunities for mitigation and adaptation. Environmental Research Letters, 4 (3), 13.

https://dx.doi.org/10.1088/1748-9326/4/3/035005

Shetty, P. K. (2004). Socio-ecological implications of pesticide use in India. Economic and Political Weekly, 39(49), 5261-5267.

Shetty, S. L. (2006). Monetary policy and financial sector liberalization in macroeconomics of poverty reduction: India case study. Report submitted to United Nations Development Program, Mumbai: Indira Gandhi Institute of Development Research.

Shiferawa, B., Reddyb, V. R., \& Wanic, S. P. (2008). Watershed externalities, shifting cropping patterns and groundwater depletion in Indian semi-arid villages: The effect of alternative water pricing policies. Ecological Economics, 67(2), 327-340.

https://dx.doi.org/10.1016/j.ecolecon.2008.05.011

Shiva, V. (2007). Agrarian Crisis in India: An overview, chapter India's agrarian suicides, pages 73-81. Hydrabad, India: The ICFAI University Press. 
Shiva, V. (2009). Why are Indian farmers committing suicide and how can we stop this tragedy? [Online] Available: http://www.voltairenet.org/article159305.html (February 13, 2018)

Shrivastava, P., \& Kumar, R. (2015). Soil salinity: A serious environmental issue and plant growth promoting bacteria as one of the tools for its alleviation. Saudi Journal of Biological Sciences, 22, 123-131. https://dx.doi.org/10.1016/j.sjbs.2014.12.001

Shroff, S. (2013). Agrarian Crisis in India: The way out, chapter - How remunerative is Indian agriculture? Focus on Maharashtra, pages 513-525. New Delhi: Academic foundation.

Singh, P. N. (2011). Chronic disease burden in rural India attributable to diet, obesity, and tobacco use. Journal of Postgraduate Medicine, 57(3), 1-2.

https://dx.doi.org/10.4103/0022-3859.76349

Sterman, J. D. (2010). Business Dynamics: Systems thinking and modeling for a complex world (3rd ed.). New Delhi: Tata McGraw-Hill.

Suri, K. C. (2007). Agrarian Crisis in India: An overview, chapter Political economy of agrarian distress, pages 53-72. Hydrabad, India: The ICFAI University Press.

Suzuki, K. (2003). Sustainable and environmentally sound land use in rural areas with special attention to land degradation. Technical Report Document 4, Asia-Pacific forum for environment and development expert meeting, Guilin, China.

Tadesse, T., Dechassa, N., Bayu, W., \& Gebeyehu, S. (2013). Effects of farmyard manure and inorganic fertilizer application on soil physico-chemical properties and nutrient balance in rain-fed lowland rice ecosystem. American Journal of Plant Sciences, 4, 309-316.

https://dx.doi.org/10.4236/ajps.2013.42041

Taylor, R., Scanlon, B., Döll, P., Rodell, M., Van B., \& Rens, (2013). Ground water and climate change. Nature Climate Change; 3 (4), 322-329.

https://dx.doi.org/10.1038/nclimate 1744

Talule, D.C. (2011), Farmers ${ }^{e e}$ Suicides in Maharashtra: A Deceased Household Level Study of the Nine Suicide Prone Districts, Indian Economic Journal, Special Issue, 97-119.

Tata Institute of Social Sciences (2005). Causes of farmer suicides in Maharashtra: An enquiry. Final Report Submitted to the Mumbai High Court. [Online] Available:

http://vnss-mission.gov.in/docs/farmers_suicide_tiss_report-2005.pdf (February 13, 2018)

Tiwari, V. M., Wahr, J., \& Swenson, S. (2009). Dwindling groundwater resources in northern India, from satellite gravity observations. Geophysical Research Letters, 36(L18401), https://dx.doi.org/10.1029/2009GL039401

Vakulabharanam, V., \& Motiram, S. (2007). Political economy of agrarian distress in India since the 1990s'. Paper presented at Columbia-LSE-New School Conference on 'Great Transformation: Understanding India's New Political Economy', New York: Columbia University. 


\section{Macrothink}

Journal of Agricultural Studies

ISSN 2166-0379

2018, Vol. 6, No. 1

Vengadaramana, A., P.T.J, \& Jashothan (2012). Effect of organic fertilizers on the water holding capacity of soil in different terrains of Jaffna peninsula in Sri Lanka. Journal of Natural Product and Plant Resources, 2(4), 500-503.

Venugopal, P. (2004). State of the Indian farmer: A millennium study - Input management, vol. 8. Technical report, New Delhi: Academic Foundation.

Whitehorn, P. R., OConnor, S., Wackers, F. L., \& Goulson, D. (2012). Neonicotinoid pesticide reduces bumble bee colony growth and queen production. Science, 336(6079), 351-352. https://dx.doi.org/10.1126/science.1215025

Wikipedia (2015). Farmers' suicides in India. [Online] Available: https://en.wikipedia.org/wiki/Farmers\%27_suicides_in_India (August 17, 2017)

Yu, L., Jun-biao, Z., \& Jiang, D. (2009). Factors affecting reduction of fertilizer application by farmers: Empirical study with data from Jianghan plain in Hubei province. Technical Report Paper 477, Contributed Paper presented at the. International Association of Agricultural Economists Conference, Beijing, China. [Online] Available:

http://ageconsearch.umn.edu/bitstream/50355/2/Factors\%20Affecting\%20Reduction\%20of\% 20Fertilizer\%20Application\%20by\%20Farmers.pdf (February 13, 2018)

Zabaloy, M. C., Zanini, G. P., Bianchinotti, V., Gomez, M. A., \& Garland, J. L. (2011). Herbicides, Theory and Applications, chapter Herbicides in the Soil Environment: Linkage between Bioavailability and Microbial Ecology, pages 161-192. Croatia: Intech.

Zilberman, D., Liu, X., Roland-Holst, D., \& Sunding, D. (2004). The economics of climate change in agriculture. Mitigation and Adaptation Strategies for Global Change, (2004) 9 (4), 365-382. https://dx.doi.org/10.1023/B:MITI.0000038844.72226.13 


\section{Macrothink}

\section{Appendix}

Appendix 1. Stock flow diagrams of the agrarian system

This appendix elaborates stock flow diagrams of six subsystems of the agrarian system. There are three major types of elements in the stock flow diagrams of the agrarian subsystems, namely, stock, flows, and auxiliary elements (Sterman, 2010). Stocks are the variables whose values get accumulated and depleted with time. These variables are depicted in rectangles in the stock flow diagrams (see all figures in the appendix). Flows are the rate of changing the values of stock variables. These variables are connected to the stock variables. Auxiliary elements are the rest of the elements of the system. An auxiliary element can be a constant, variable, or a function of a number of auxiliary elements. Agrarian system is assumed to broadly comprise six stock variables forming six respective subsystems. These are indebtedness of farmer, land fertility, water table, cattle population, average farm size, and human population. The stock flow diagrams of these subsystems are given in figures 12,13 , $14,15,16$, and 17. A dependent variable is connected to the other variables or constants by arrows. Positive sign (polarity) on an arrow shows that an increasing trend of a variable imparts an increasing trend to its dependent variable. A negative polarity implies the opposite. 


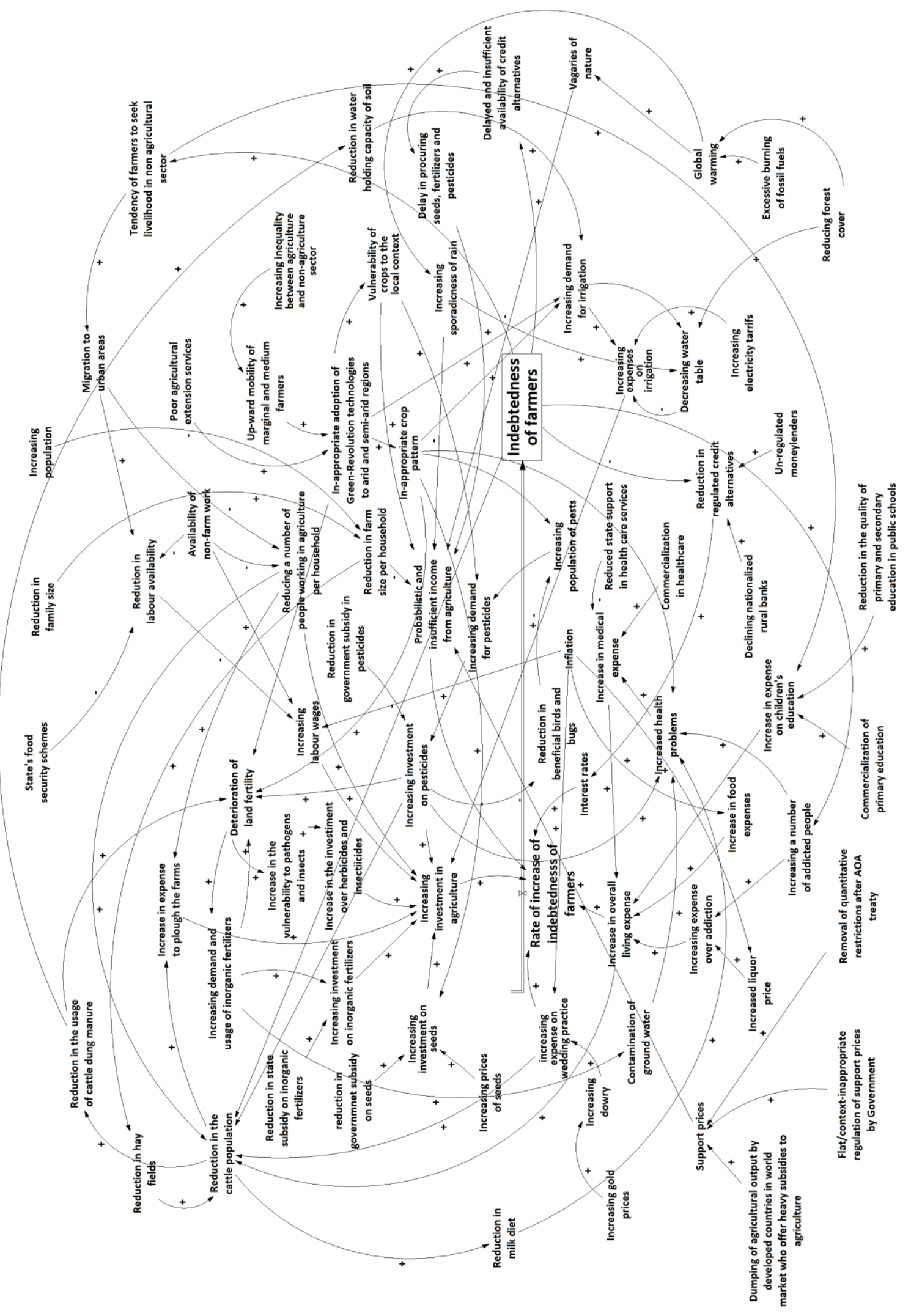

Figure 12: A stock-flow diagram of indebtedness of farmers: a total of 39 self-reinforcing loops and 78 elements 


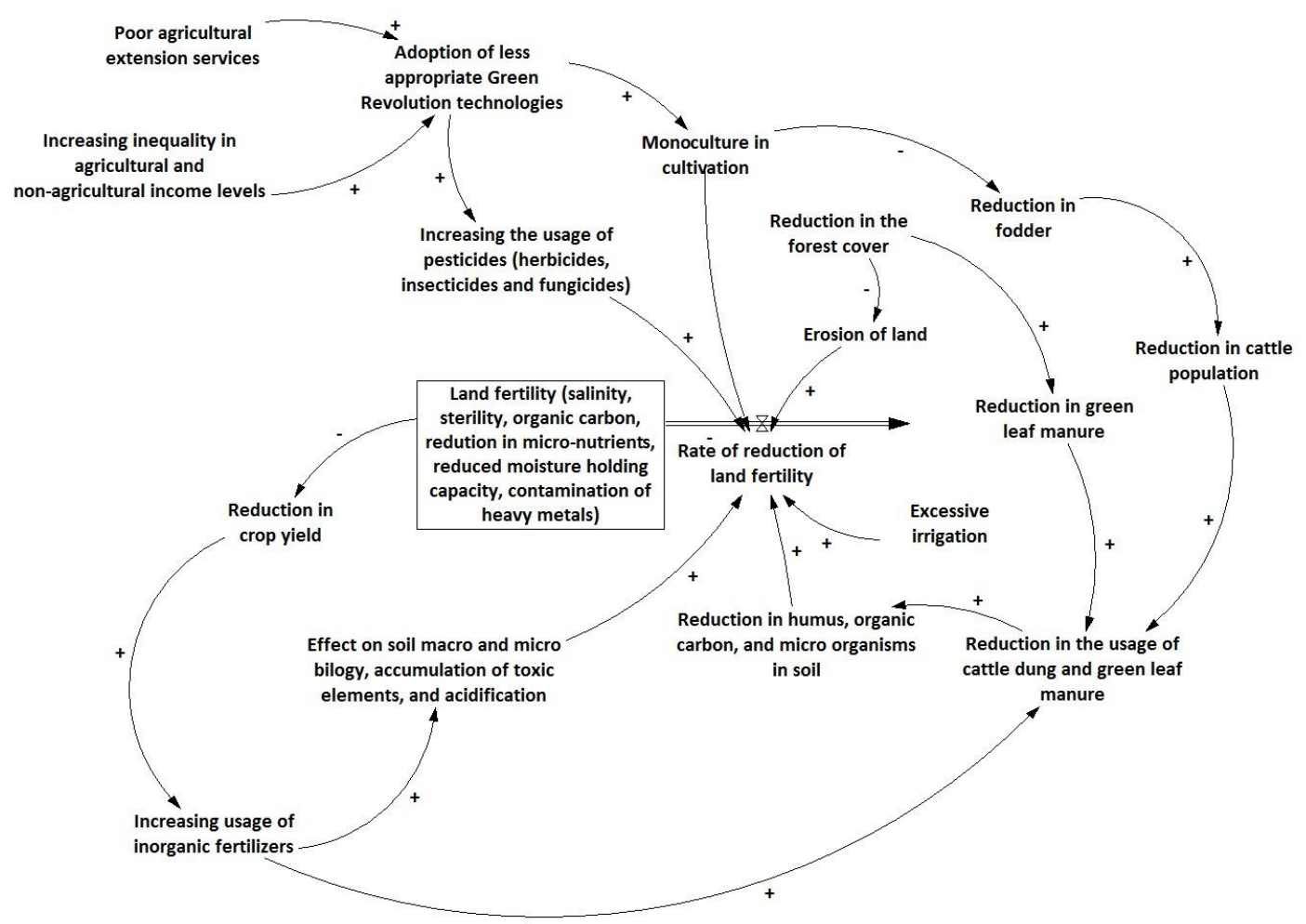

Figure 13: A stock-flow diagram of land fertility: a total of 2 self-reinforcing loops and 18 elements

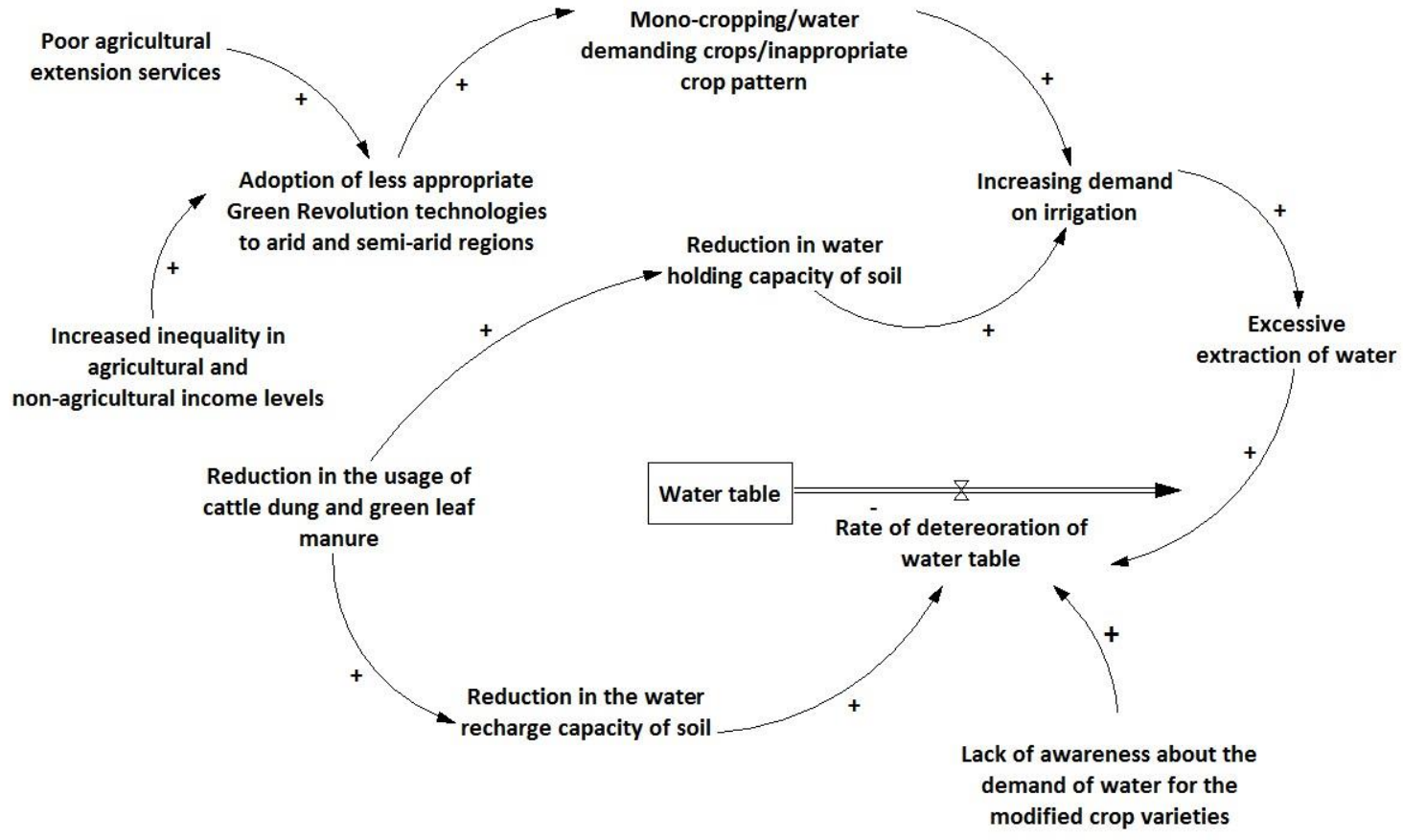

Figure 14: A stock-flow diagram of water table: a total of 12 elements 


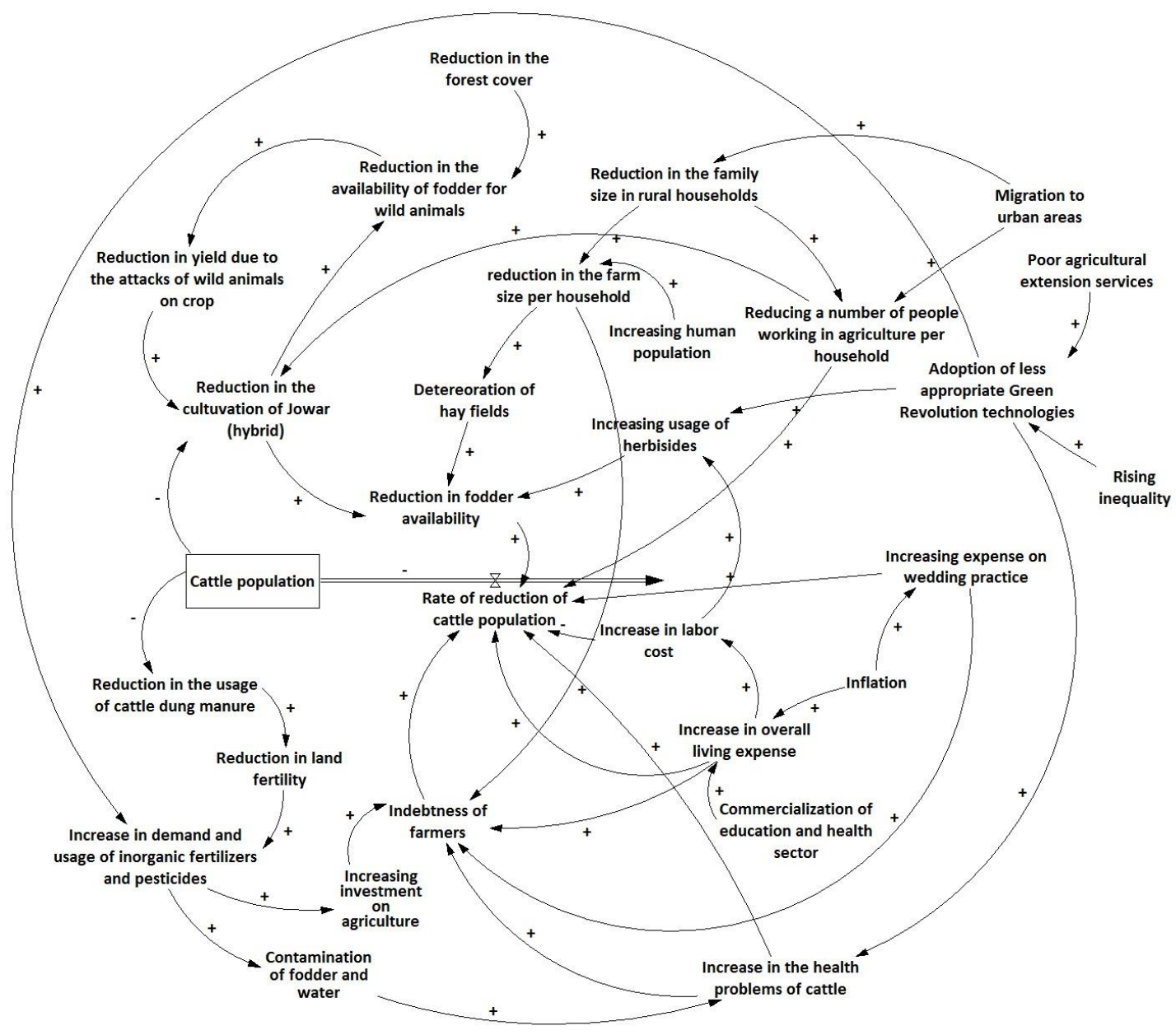

Figure 15: A stock-flow diagram of cattle population: a total of 4 self-reinforcing loops and 29 elements

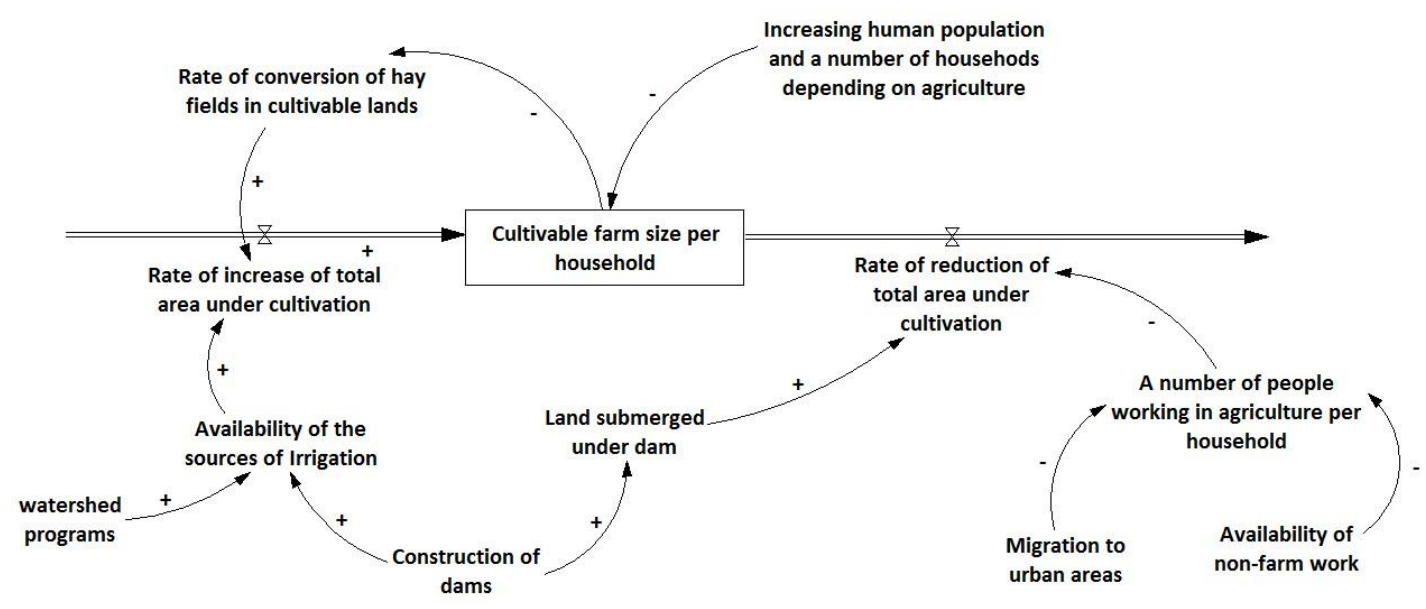


Figure 16: A stock-flow diagram of farm size per household: a total of 12 elements

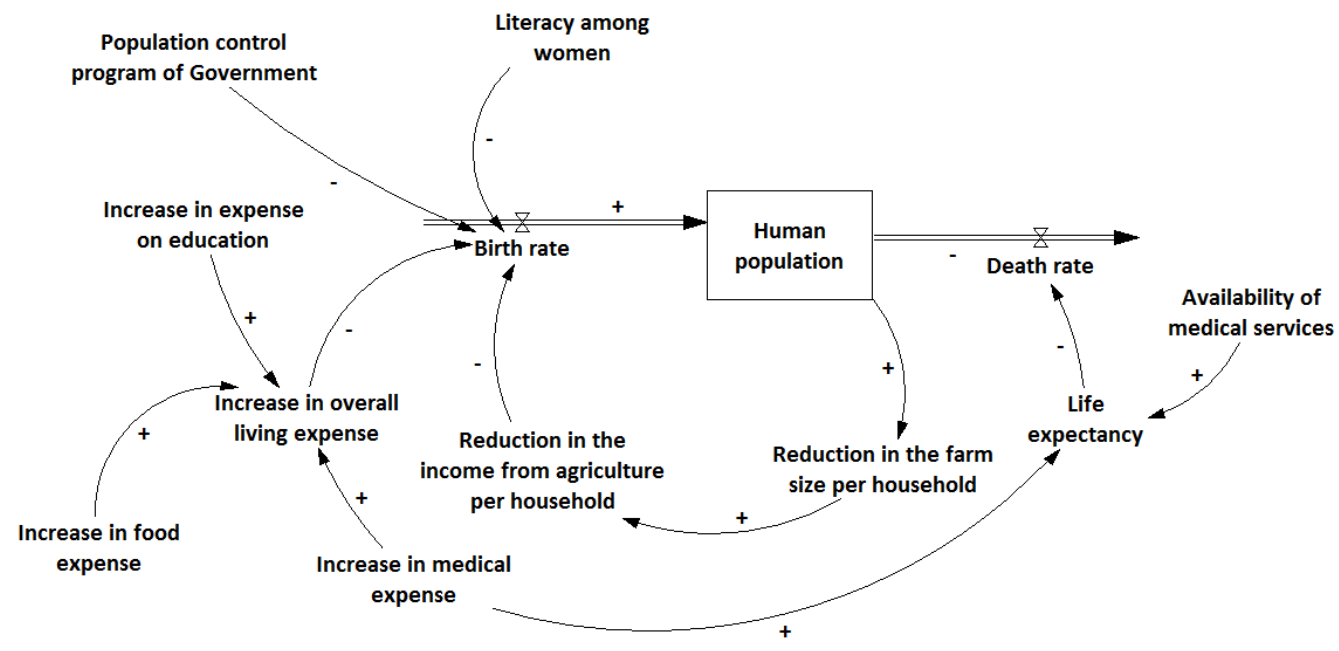

Figure 17: A stock-flow diagram of human population: A total of 13 elements

\section{Copyright Disclaimer}

Copyright for this article is retained by the author(s), with first publication rights granted to the journal.

This is an open-access article distributed under the terms and conditions of the Creative Commons Attribution license (http://creativecommons.org/licenses/by/4.0/). 